Avaliação comparativa do tratamento cirúrgico da hérnia perineal em cães pela técnica de elevação do músculo obturador interno com ou sem reforço de retalho de membrana de pericárdio eqüino preservado em glicerina a $98 \%$ 


\section{Avaliação comparativa do tratamento cirúrgico da hérnia perineal em cães pela técnica de elevação do músculo obturador interno com ou sem reforço de retalho de membrana de pericárdio eqüino preservado em glicerina a $98 \%$}

Dissertação apresentada ao Programa de Pósgraduação em Cirurgia da Faculdade de Medicina Veterinária e Zootecnia da Universidade de São Paulo para obtenção do título de Mestre em Medicina Veterinária

Departamento:

Cirurgia

Área de Concentração:

Cirurgia

Orientador:

Prof. Dr. Angelo João Stopiglia

São Paulo 
Autorizo a reprodução parcial ou total desta obra, para fins acadêmicos, desde que citada a fonte.

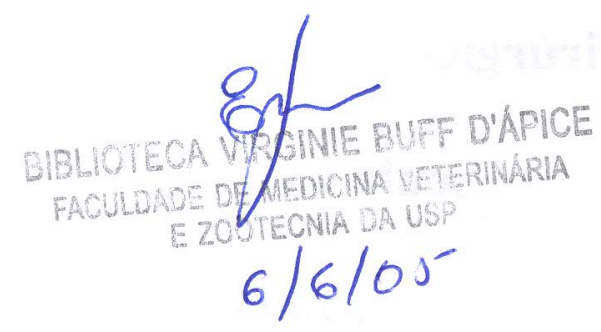

DADOS INTERNACIONAIS DE CATALOGAÇÃO-NA-PUBLICAÇÃO

(Biblioteca da Faculdade de Medicina Veterinária e Zootecnia da Universidade de São Paulo)

T.1522 Zerwes, Maria Beatriz Cattony

FMVZ Avaliação comparativa do tratamento cirúrgico da hérnia perineal em cães pela técnica de elevação do músculo obturador interno com ou sem reforço de retalho de membrana de pericárdio eqüino preservado em glicerina a 98\% / Maria Beatriz Cattony Zerwes, - São Paulo : M. B. C. Zerwes, 2005.

$91 \mathrm{f}$ : : il.

Dissertação (mestrado) - Universidade de São Paulo. Faculdade de Medicina Veterinária e Zootecnia. Departamento de Cirurgia, 2005.

Programa de Pós-graduação: Cirurgia.

Área de concentração: Cirurgia.

Orientador: Prof. Dr. Angelo João Stopiglia.

1. Hernia perineal. 2. Herniorrafia. 3. Cães. 4. Pericárdio. 5. Glicerina $98 \%$. I. Título. 


\section{UNIVERSIDADE DE SÃO PAULO \\ Faculdade de Medicina Veterinária e Zootecnia \\ Cidade Universitária "Armando de Salles Oliveira" \\ Comissão Bioética

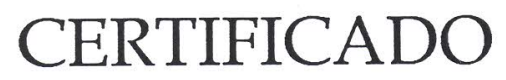

Certificamos que o Projeto intitulado "Tratamento cirúrgico da hérnia perineal em cães pela técnica de elevação do músculo obturador interno com ou sem reforço de retalho de membrana de pericárdio eqüino preservado em glicerina a 98\%", protocolo $n^{\circ} 307 / 2003$, utilizando 10 cães, sob a responsabilidade do Prof. Dr. Angelo João Stopiglia, está de acordo com os princípios éticos de experimentação animal da Comissão de Bioética da Faculdade de Medicina Veterinária e Zootecnia da Universidade de São Paulo e foi aprovado "ad referendun".

(We certify that the Research "Surgery treatment of perineal hernia in dogs by transposition of the internal obturator muscle with or without equine sac preserved in glycerine 98\% " protocol number 307/2003, utilizing 10 dogs, under the responsibility of Prof. Dr. Angelo João Stopiglia, agree with Ethical Principles in Animal Research adopted by Biotic Commission of the Faculty of Veterinary Medicine and Zootechny of University of São Paulo and was approved "ad referendun").

São Paulo, 14 de maio de 2003

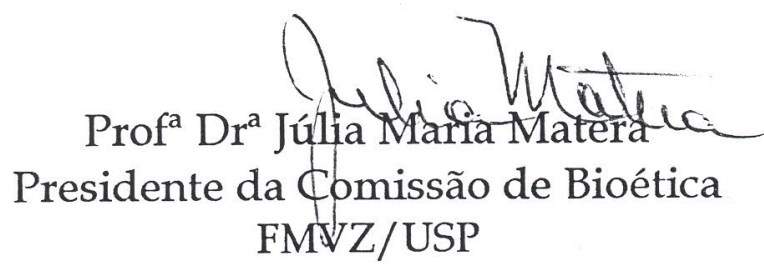




\section{FOLHA DE AVALIAÇÃO}

Nome: ZERWES, Maria Beatriz Cattony

Título: Avaliação comparativa do tratamento cirúrgico da hérnia perineal em cães pela técnica de elevação do músculo obturador interno com ou sem reforço de retalho de membrana de pericárdio eqüino preservado em glicerina a $98 \%$

Dissertação apresentada ao Programa de Pós - graduação em Cirurgia da Faculdade de Medicina Veterinária e Zootecnia da Universidade de São Paulo para obtenção do título de Mestre em Medicina Veterinária

Data:

Banca examinadora

Prof. Dr. Instituição:

Assinatura: Julgamento:

Prof. Dr. Instituição:

Assinatura: Julgamento:

Prof. Dr. Instituição:

Assinatura: Julgamento: 


\section{DEDICATÓRIA}

Aos meus pais, Júlio e Lela, que sempre acreditaram, apoiaram e incentivaram todos os projetos pelos quais participei.

Ao meu orientador Prof. Dr. Angelo João Stopiglia pela dedicação dispensada a esta pupila.

A Prof. Dra. Júlia Maria Matera, que sempre me acolheu no Serviço de Cirurgia de Pequenos Animais da FMVZ/USP. 


\section{AGRADECIMENTOS}

Aos professores Angelo João Stopiglia e Júlia Maria Matera, pois sem o apoio de ambos, seria impossível concluir este projeto.

Ao professor Franklin pela oportunidade de trabalharmos juntos na elaboração das radiografias e por mostrar-se sempre atencioso e disponibilizar o Serviço de Imagem para enriquecer esta obra.

Aos colegas do Serviço de Cirurgia de Pequenos Animais: Sandra, Viviane, Andressa, Tatiana, Patrícia, Genilson e Angélica pela paciência e "socorro” prestados ao longo destes anos.

Aos meus primeiros “mestres” que desde quando aluna já me ensinavam a realizar pequenos procedimentos: Lelis, Maurício, Jesus, Otávio e Miron.

A todos do Serviço de Anestesia, pelo acompanhamento realizado nos meus pacientes velhinhos.

Aos colegas de pós-graduação, residentes e Neuzinha pela amizade e coleguismo.

Ao Conselho Nacional de Desenvolvimento Científico e Tecnológico (CNPq) por todo auxílio financeiro para a conclusão desta pesquisa.

Muito obrigada a todos. 


\section{RESUMO}

ZERWES, M. B. C. Avaliação comparativa do tratamento cirúrgico da hérnia perineal em cães pela técnica de elevação do músculo obturador interno com ou sem reforço de retalho de membrana de pericárdio eqüino preservado em glicerina a $98 \%$. [Comparative evaluation of perineal hernia surgical treatment in dogs through the internal obturator transposition thechnique with or without equine pericardium preserved in glycerine 98\%]. 2005. 91 f. (Mestrado em Medicina Veterinária) - Faculdade de Medicina Veterinária e Zootecnia, Universidade de São Paulo, São Paulo, 2005.

A hérnia perineal é paratopia comum em cães machos, idosos, não castrados, cuja etiologia ainda não está bem esclarecida. O tratamento definitivo é a herniorrafia, embora a incidência de falha cirúrgica e as recidivas com o método de reparação padrão seja elevado. O objetivo do presente trabalho foi o de comparar duas técnicas de reparação cirúrgica da hérnia perineal unilateral. Para tanto utilizou-se 10 cães triados pelo HOVET-FMVZ/USP e encaminhados ao Serviço de Cirurgia de Pequenos Animais da mesma faculdade. Os animais foram divididos em dois grupos com cinco representantes em cada um. A hérnia perineal foi corrigida pela técnica de elevação do músculo obturador interno em ambos os grupos. O segundo grupo teve reforço no diafragma pélvico com enxerto heterotópico e xenólogo de retalho de pericárdio de eqüino puro sangue inglês conservado em glicerina a 98\%, após a técnica de elevação do músculo obturador intern. Os animais foram avaliados por até 90 dias de pós-operatório, mediante análise clínica, ultra-sonografia e radiográfica da região perineal. Os resultados obtidos demonstraram que houve reforço no local da herniorrafia ao se fixar o pericárdio de eqüino conservado em glicerina a 98\%, diminuindo a ocorrência de deiscência dos pontos da musculatura ou ruptura do diafragma operado.

Palavras Chaves: Hérnia perineal. Herniorrafia. Cães. Pericárdio. Glicerina 98\%. 


\begin{abstract}
ZERWES, M. B. C. Comparative evaluation of perineal hernia surgical treatment in dogs through the elevation of the internal obturator or transposition thechnique with or without equine pericardium preserved in glycerine $\mathbf{9 8 \%}$. [Avaliação comparativa do tratamento cirúrgico da hérnia perineal em cães pela técnica de elevação do músculo obturador interno com ou sem reforço de retalho de membrana de pericárdio eqüino preservado em glicerina a 98\%]. 2005. 91 f. (Mestrado em Medicina Veterinária) - Faculdade de Medicina Veterinária e Zootecnia, Universidade de São Paulo, São Paulo, 2005.
\end{abstract}

The perineal hernia is a common disease in old, not sterilized, male dogs, whose etiology isn't clear, yet. The definitive treatment is the herniorrhaphy, but the surgical failure and the recurrence rate with traditional reapposition technique is high. The purpose of this present study was to compare two techniques of surgical reparation of the unilateral perineal hernia. To achieve this, we used 10 dogs from the HOVET-FMVZ/USP that were lead to the Service of Small Animal Surgery at the same college. The animals were disposed in 2 groups with 5 representatives each. The perineal hernia was operated by the elevation of the internal obturator or transposition thechnique in both groups. One of these groups was reinforced in their pelvic diaphragms with graft heterotopy and xenogenic from Thoroughbred horse equine pericardium conserved in glycerine at $98 \%$, after the elevation of the internal obturator or transposition thechnique. The animals were examined within 90 days after operation, through clinical analysis, ultrasonography and radiography of the perineal local. The results showed that the local of herniorrhaphy had been reforced by implant of graft heterotopy and xenogenic from Thoroughbred, reducing the recidive of hernia perineal.

Key works: Perineal hernia. Herniorrhaphy. Dogs. Pericardium. Glycerine 98\%. 


\section{LISTA DE QUADROS E GRÁFICO}

APÊNDICE A - $\quad$ Informações alusivas ao tipo de moradia, raça, idade, peso e diagnóstico original dos animais da espécie canina, machos, portadores de hérnia perineal submetidos a tratamento cirúrgico por elevação do músculo obturador interno com ou sem retalho de pericárdio de eqüino conservado em glicerina a $98 \%$

APÊNDICE B - D Dados referentes à evolução, sintomas observados, aspecto das fezes e escore de evacuação pertinente aos animais, portadores de hérnia perineal submetidos a tratamento cirúrgico por elevação do músculo obturador interno com ou sem retalho de pericárdio de eqüino conservado em glicerina a $98 \%$.

APÊNDICE C - $\quad$ Aspectos relacionados à consistência da região perineal, órgãos palpáveis e observados ao ultra-som, exame radiográfico e durante o transoperatório nos animais submetidos a tratamento cirúrgico por elevação do músculo obturador interno com ou sem retalho de pericárdio de eqüino conservado em glicerina a $98 \%$

APÊNDICE D - Tempo de evolução, lado acometido e condição da musculatura durante o período transoperatório nos pacientes submetidos a herniorrafia por elevação do músculo obturador interno com ou sem reforço de retalho de pericárdio de eqüino.

APÊNDICE D - $\quad$ Lado acometido, conteúdo transoperatório e complicações operatórias (PO) imediatas e tardias, nos animais submetidos à herniorrafia por elevação do músculo obturador interno sem reforço de retalho de pericárdio eqüino.

APÊNDICE E - $\quad$ Lado acometido, conteúdo transoperatório e complicações pós operatórias (PO) imediatas e tardias, nos animais submetidos à herniorrafia por elevação do músculo obturador interno com reforço de retalho de pericárdio eqüino.

APÊNDICE F - Dados referentes à condição da musculatura durante o transoperatório dos animais submetidos a herniorrafia por elevação do músculo obturador interno com ou sem retalho de membrana pericárdio de eqüino, considera-se 1 atrofia severa com ausência de visualização muscular; 2 atrofia moderada; 3 atrofia discreta e 4 ausência de atrofia muscular. 


\section{LISTA DE FIGURAS}

Apêndice G - $\quad$ Herniorrafia por elevação do músculo obturador interno associado a colocação de membrana pericárdio de eqüino conservado em glicerina a 98\%. Intervenção cirúrgica animal n. 7 (Figuras 1 a 6 )

Apêndice H - Pós-operatório de herniorrafia por elevação do músculo obturador interno associado a colocação de membrana pericárdio de eqüino conservado em glicerina a 98\%. Animal n. 7 (Figuras 7 a 12)

Apêndice I -

Preparo do paciente para herniorrafia por elevação do músculo obturador interno associado a colocação de membrana pericárdio de eqüino conservado em glicerina a 98\%. Animal n. 9 (Figuras 13 a 18)

Apêndice $J$ -

Herniorrafia por elevação do músculo obturador interno associado a colocação de membrana de pericárdio de eqüino conservado em glicerina a 98\%. Intervenção cirúrgica animal n. 9 (Figuras 19 a 22) 89

Apêndice K - Pós-operatório de herniorrafia por elevação do músculo obturador interno associado a colocação de membrana pericárdio de eqüino conservado em glicerina a 98\%. Animal n. 9 (Figuras 23 a 28)

Apêndice L -

Preparo da membrana pericárdio de eqüino conservado em glicerina a $98 \%$ e aplicação sobre a herniorrafia por elevação do músculo obturador interno (Figuras 29 a 33) 


\section{SUMÁRIO}

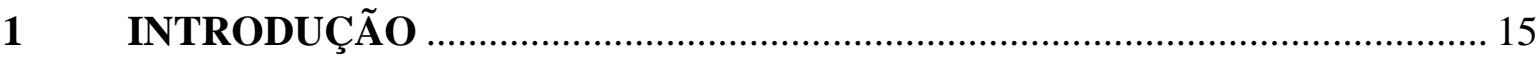

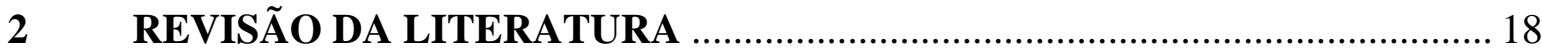

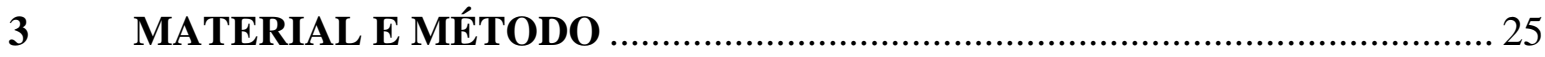

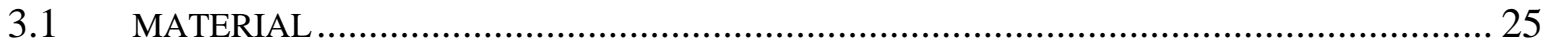

3.1.1 Pacientes (animais utilizados) ……………………......................................... 25

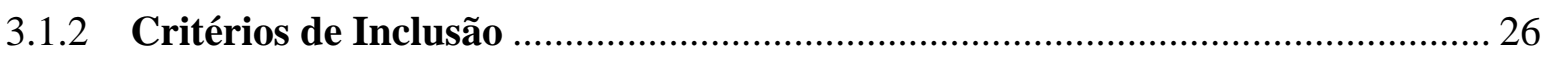

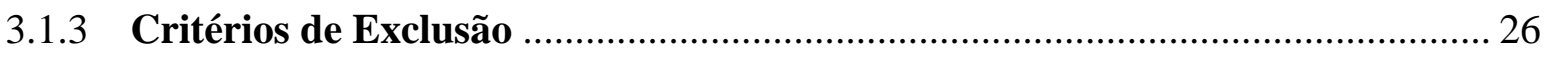

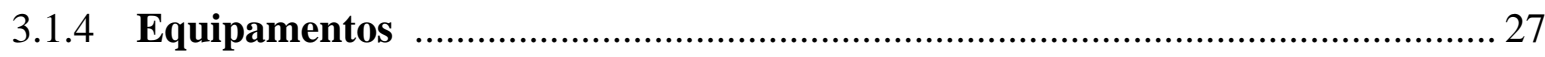

3.1.4.1 Material Cirúrgico ……………………………………………………………. 27

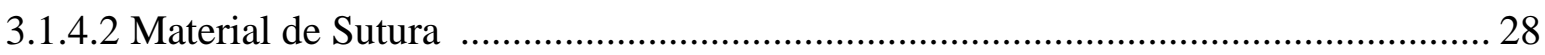

3.1.4.3 Membrana Biológica ....................................................................................... 28

3.1.4.4 Exame Ultra-sonográfico ……………………….............................................. 29

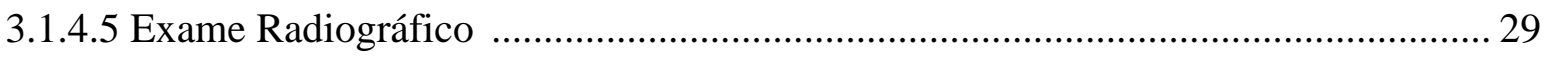

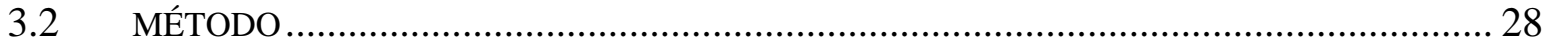

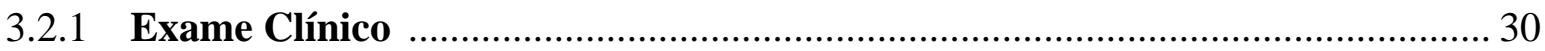

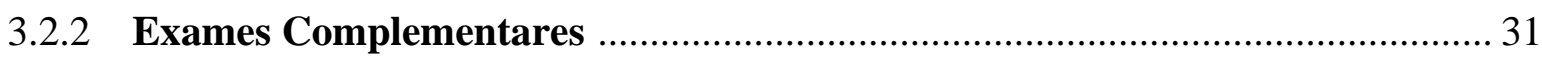

3.2.2.1 Interpretação do Exame Eletrocardiográfico ............................................................. 31

3.2.2.2 Interpretação dos Exames Laboratoriais .................................................................. 32

3.2.2.3 Interpretação dos Exames de Imagem ....................................................................... 33

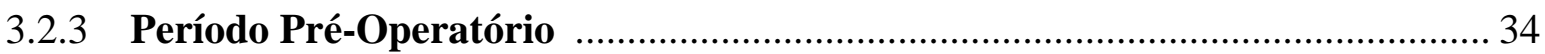

3.2.4 Procedimento Cirúrgico ………………………................................................ 35

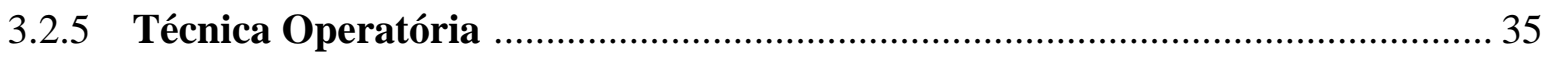

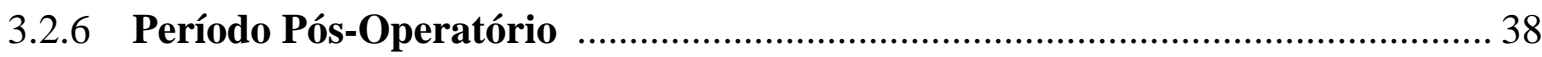




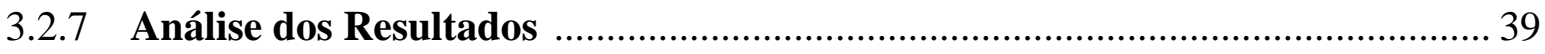

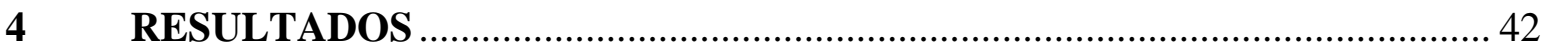

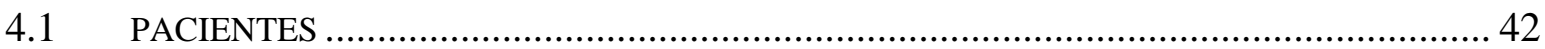

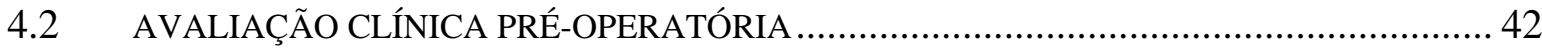

4.2.1 Aspecto Clínico da Hérnia Perineal ................................................................... 45

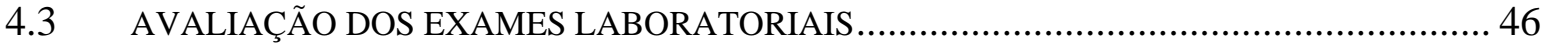

4.4 AVALIAÇÃO DOS EXAMES PRÉ-OPERATÓRIOS DE IMAGEM ULTRA-SONOGRÁFICA.. 46

4.5 AVALIAÇÃO DOS EXAMES PRÉ-OPERATÓRIOS DE IMAGEM RADIOGRÁFICA ............ 48

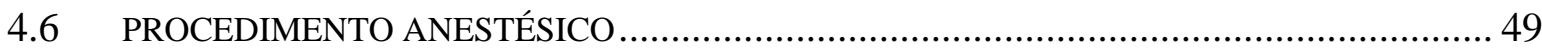

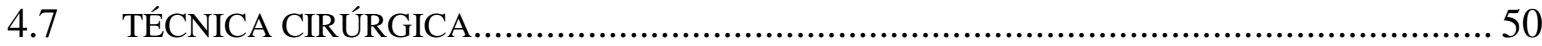

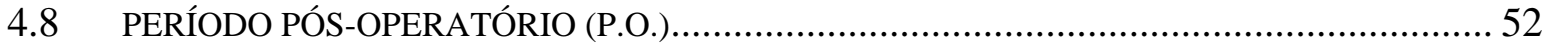

4.9 AVALIAÇÃO DOS EXAMES TARDIOS PÓS-OPERATÓRIOS DE IMAGEM ULTRA-

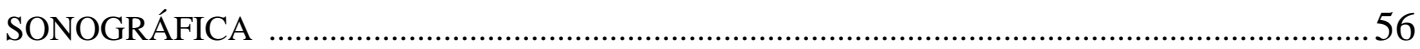

4.10 AVALIAÇÃO DOS EXAMES TARDIOS PÓS - OPERATÓRIOS DE IMAGEM

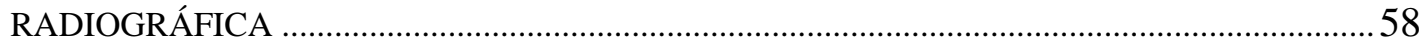

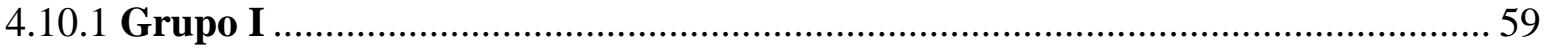

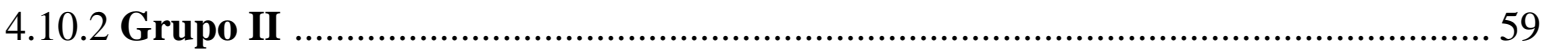

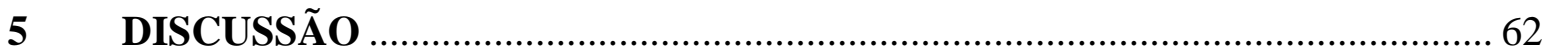

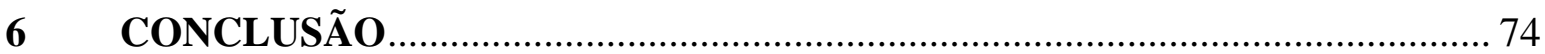

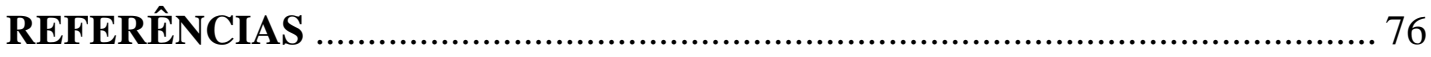

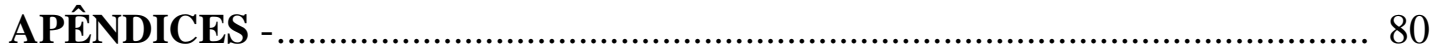


I - INTRODUÇÃO 


\section{INTRODUÇÃO}

A observação diária e as complicações pré e pós-operatórias da hérnia perineal dos cães é um fator constante de preocupação ao cirurgião veterinário, fato que tem suscitado a descrição de diversas técnicas na literatura a fim de solucionar os aludidos aspectos. Apesar disto, a hérnia perineal ainda constitui-se em desafio para os pesquisadores, por enquanto as referidas complicações são constatadas ainda, nos dias atuais.

A hérnia perineal acomete principalmente animais machos da espécie canina, de idade superior a cinco anos (HEDLUND, 2002). Caracteriza-se pela perda da integridade do diafragma pélvico, que é formado pela junção dos músculos elevador do ânus, coccígeo e esfíncter anal externo. O conteúdo e a consistência da hérnia pode ser variado, mas a hérnia distingue-se por aumento óbvio de volume na região perineal, lateral ao ânus (EVANS et al., 1979; ROCHAT et al., 1998).

Técnicas cirúrgicas foram idealizadas para a reconstrução da função do diafragma pélvico, especialmente nas hérnias muito desenvolvidas, que constituem o principal obstáculo para o tratamento no cão (MATERA et al., 1981). Assim, a ocorrência de complicações pós-operatórias e as recidivas ou falha na reparação cirúrgica, por uma série de fatores, é o principal problema encontrado na resolução desta paratopia (SJOLLEMA et al., 1989; WEAVER et al., 1981).

As técnicas já empregadas referem-se a herniorrafia simples ou padrão, a herniorrafia por transposição ou elevação do músculo obturador interno, a herniorrafia por transposição do músculo glúteo superficial e a utilização de materiais biológicos para obliterar o orifício herniário, como o peritônio bovino e o colágeno dérmico suíno 
ou malha sintéticas como o polipropileno (DALECK et al., 1992; FRANKLAND et al., 1986; MATERA et al., 1981; SJOLLEMA et al., 1989).

A incidência de complicações pós-operatórias e de recidivas, variam conforme o método empregado para a reparação. A que se tem utilizado mais freqüentemente, com menor probabilidade de recidiva e complicações é a herniorrafia por transposição ou elevação do músculo obturador interno (SJOLLEMA et al., 1989). A utilização de malha sintética mostrou-se efetiva e com excelentes resultados, mas o custo do material é um dos fatores limitantes para o seu uso corriqueiro em medicina veterinária (MATERA et al., 1981). Resultados também positivos foram obtidos quando se empregou apenas membrana biológica, peritônio bovino conservado em glicerina a 98\%, tendo como principal complicação pós-operatória, a infecção no sítio cirúrgico (DALECK et al., 1992).

A utilização de membrana biológica em medicina veterinária é ampla. Estendese desde sua aplicação em vários tipos de cirurgias corretivas, por exemplo, nos defeitos penetrantes de córnea (BARROS et al., 1997), reparação traqueal (CONTENSINI et al., 2001), em parede torácica (STOPIGLIA et al., 1986) e em esôfago cervical (FREITAS et al., 2002), entre outros. É material de fácil obtenção, barato, pode ser armazenado em recipientes estéreis preparados para o devido fim.

O objetivo deste trabalho é o de verificar comparativamente a eficiência do emprego da membrana biológica de pericárdio de eqüino na correção da hérnia perineal unilateral, como reforço da reconstrução cirúrgica do diafragma pélvico quando utilizada a técnica de elevação do músculo obturador interno, no intuito de averiguar-se a sua aplicação para a redução dos índices da referida paratopia. 
II - REVISÃO DA LITERATURA 


\section{REVISÃO DA LITERATURA}

A hérnia perineal é paratopia comum típica de cães machos idosos (MANN et al.,1998), resultante da fraqueza e separação dos músculos e fáscia do diafragma pélvico (HOSGOOD et al., 1995), permitindo o deslocamento com posicionamento caudal dos conteúdos abdominais e/ou pélvicos no interior da fossa ísquioretal (SJOLLEMA et al.,1993) com conseqüente distensão da pele do períneo (HEDLUND,1997; HOSGOOD et al.,1995). A dificuldade na função de sustentação do diafragma pélvico é considerada como parte integrante ou como pré-condição para o desenvolvimento da hérnia perineal. Em muitos casos de hérnia perineal, a porção caudal do músculo elevador do ânus não é observada, devido à atrofia (SJOLLEMA et al., 1993).

A etiologia da hérnia perineal ainda não está totalmente esclarecida. Diversas teorias são propostas, dentre elas a de que fatores hormonais e neurogênicos estariam envolvidos (MANN et al., 1995; SJOLEMA et al., 1993). Acreditava-se que os testículos secretariam estrógeno em excesso, tornando o diafragma pélvico relaxado e propenso a sofrer herniação (PETIT, 1962). No entanto, pesquisas mais recentes demonstraram que o nível sérico de testosterona e estradiol-17 no cão com hérnia perineal não diferem daqueles clinicamente sadios (MANN et al., 1989). Posteriormente, foi observado que os receptores de andrógenos no músculo elevador do ânus e músculo coccígeo estão reduzidos em número, nos cães portadores de hérnia perineal castrados ou não (MANN et al., 1995).

O aumento da próstata e a presença de enfermidades no reto (desvio, dilatação, flexura e saculação) têm sido implicados como contribuintes para a herniação (RAISER et al., 1994), por induzir tenesmo, atrofia e enfraquecimento do músculo elevador do 
ânus (DORN et al., 1982). As afecções retais mais comumente encontradas são: desvio de reto (100\%) e dilatação da ampola retal (menos de 40\%) (HOSGOOG et al., 1995). Divertículo retal não é achado comum. Em estudo com 100 cães portadores da hérnia perineal em que realizou-se herniorrafia em nenhum deles constatou-se divertículo retal (HOSGOOD et al., 1995). Ainda, são considerados fatores que também podem contribuir para o aparecimento da hérnia perineal: a constipação crônica e o esforço para defecar secundário às cistites e diarréias persistentes (HOGOOD et al., 1995).

A hérnia perineal é observada principalmente em cães machos, idosos (sete aos 14 anos, com média de nove anos (DALECK et al., 1992; MATERA et al., 1981; RAISER et al., 1994; WEAVER et al., 1981), não castrados (93\%), (DORN et al., 1982). As raças de cães com maior predisposição a apresentarem a aludida paratopia são o sem raça definida (SRD), o dachshund, o old english sheepdog, o pastor alemão, o pinsher, o poodle, o chihuahua, o lhasa apso (ORSHER et al., 1986), o boston terrier, o boxer (DORN et al., 1982) e o collie e seus mestiços (DELAI et al., 1982, DORN et al., 1982).

A hérnia perineal pode ser unilateral 65\% (WEAVER et al., 1981) e 42,58\% (RAISER et al., 1994) ou bilateral 36\% (WEAVER et al., 1981) e 57,42\% (RAISER et al., 1994). Alguns autores descrevem que o acometimento unilateral direito é mais freqüente que no esquerdo (DALECK et al., 1992; DESAI et al., 1982; WEAVER et al., 1981).

A hérnia perineal pode ser classificada segundo a região anatômica em dorsal e ventral, tendo como referência a linha entre o centro do orifício anal e a tuberosidade isquiática (ORSHER et al., 1986). Alguns autores, entretanto sugerem que a descrição da região perineal canina pode fornecer bases para outra classificação, em que estas apresentam-se em quatro tipos: dorsal, ventral, caudal e ciática (DORN et al., 1982; 
HEDLUND, 1997; MANN et al., 1998). A hérnia caudal é a mais comumente encontrada, enquanto que a hérnia ciática é a mais rara (HOSGOOD et al., 1995).

Os conteúdos da hérnia perineal estão envoltos por fina camada de fáscia perineal (saco herniário), tecido subcutâneo e pele. O saco herniário pode conter gordura pélvica ou retroperineal, fluido seroso, reto desviado ou dilatado, próstata, vesícula urinária 60\% (RAISER et al., 1994), vesícula urinária retrofletida (DALECK et al., 1992) 20\% (HOSGOOD et al., 1995) ou intestino (HEDLUND, 1997). Os órgãos contidos no saco herniário podem tornar-se obstruído ou estrangulados, agravando-se rapidamente o estado geral do paciente (DALECK et al., 1992) 20\% (HOSGOOD et al., 1995; HEDLUND, 1997).

Os sintomas observados pelo proprietário são variáveis, de acordo com o conteúdo do saco herniário. As queixas mais freqüentes são o aumento de volume em região perineal, tenesmo e disquesia, podendo, ainda, ser relatado a estrangúria, hematúria, incontinência urinária e fecal. (SJOLLEMA et al., 1989). O esforço e a compressão exercidas vezes durante a evacuação, resultam, eventualmente, em lesão irreversível do nervo pudendo, danificando-se a função do esfíncter anal (SJOLLEMA et al., 1989).

Os achados físicos encontrados pelo médico veterinário durante o exame clínico são: o aumento de volume em região perineal redutível ou não, sendo de consistência mole e/ou flutuante. É possível por meio da palpação digital externa e pela palpação retal, detectar-se o provável conteúdo herniário. Pela palpação retal constata-se o desvio de reto, a perda da continuidade e/ou enfraquecimento do diafragma pélvico, a compactação fecal e a prostatomegalia (HOSGOOD et al., 1995; MANN et al., 1998). Na presença de aumento não redutível em região perineal, deve-se verificar a presença ou não da vesícula urinária que pode estar retrofletida no interior da herniação. O exame 
radiográfico da região ou mesmo o exame de ultra-som são extremamente úteis para avaliar-se o conteúdo do saco herniário. Os exames de dosagem sérica de uréia e creatinina auxiliam na avaliação do estado clínico do animal que se encontra com a vesícula urinária retrofletida e provavelmente com obstrução do trato urinário. (DIETERICH, 1975; HEDLUND, 1997; ROBERTSON et al., 1983).

A conduta paliativa de manejo do paciente com hérnia perineal pode ser feito de forma conservativa com o uso de emolientes, enemas periódicos, ocasionalmente remoção digital das fezes e a utilização de fibras na dieta que tornem o bolo fecal mais macio (DIETERICH, 1975). O tratamento definitivo baseia-se na herniorrafia que reconstitui o diafragma muscular pélvico, restabelecendo a função de suporte desta região.

A incidência de falha cirúrgica e as recidivas com o método de reparação padrão varia de 10 a 46\% (SJOLLEMA et al., 1989). Para solucionar este problema, técnicas cirúrgicas alternativas tais como: a transposição do músculo glúteo superficial, a elevação do músculo obturador interno e a aplicação de malha sintética têm sido utilizadas (MANN et al., 1989; MATERA et al., 1981; SJOLLEMA et al., 1989). Dentre estas técnicas, a utilizada com maior sucesso é a da elevação do músculo obturador interno (EARLY; KOLATA, 1983; OSHER; JOHNSTON, 1985; OSHER, 1986) e suas modificações (VANS SLUIJS; SJOLLEMA et al., 1989), pois permite fechamento da região de forma mais anatômica com menos força de tensão entre as suturas aplicadas para corrigir o defeito (ORSHER et al., 1986). Alguns autores procuraram realizar a correção cirúrgica do diafragma pélvico através da obliteração mediante adaptação de malhas sintéticas tais como as de malha de polipropileno (CLARKE et al., 1989; MATERA et al., 1981), ou de membranas biológica como o centro frênico eqüino (ALVARENGA et al., 1978), colágeno dérmico suíno 
(FRANKLANDL, 1986) e peritônio bovino (DALECK et al., 1992). Matera et al. (1981) e Daleck et al. (1992), utilizaram malha de polipropileno e peritônio de bovino, respectivamente, fixando-as diretamente na musculatura após a redução do conteúdo herniado obtendo resultados satisfatórios, com boa reparação do diafragma pélvico. As principais complicações pós-operatórias observadas quanto à utilização de membrana biológica são semelhantes às demais técnicas, e diz respeito à deiscência de pontos, devido ao processo infeccioso e à recidiva de hérnia perineal (DALECK et al., 1992).

A herniorrafia perineal tem sido associado a um alto índice de complicações pós-operatórias, que incluem recidiva, infecção com formação de abscessos e fístulas retocutâneas conseqüentes à penetração de suturas na mucosa retal (MANN et al., 1998; MATTHIESSEN et al., 1989), tenesmo, prolapso retal, incontinência fecal, incontinência urinária e lesão do nervo ciático (HOSGOOD et al., 1995). Estes últimos autores observaram que 35\% das complicações eram incisionais, seguidos do prolapso retal (9\%), tenesmo (8\%) e incontinência urinária (10\% dos cães que apresentaram vesícula urinária retrofletida). Neste mesmo estudo verificou-se taxa de mortalidade de 30\% entre os cães com vesícula urinária retrofletida (HOSGOOD et al., 1995).

A recidiva da hérnia perineal tem sido associado indiretamente com a inexperiência do cirurgião e/ou técnica inadequada (HOSGOOD et al., 1995; SJOLLEMA et al., 1989). A recidiva demonstra ser menor quando se emprega a técnica de elevação do músculo obturador interno (HOSGOOD et al., 1995). Foi observada recidiva de 10 a $46 \%$ utilizando-se a técnica de herniorrafia padrão, recidiva de $14 \%$ com a técnica de transposição do músculo glúteo e 4,6\% com a técnica de elevação do músculo obturador interno (SJOLLEMA et al., 1989).

As infecções pós-operatórias podem ser detectadas a partir do terceiro ao quinto dia após a cirurgia e está associado com depressão física, anorexia, febre e edema na 
área perineal (SJOLLEMA et al., 1989). Tais autores constataram que entre 5 a 29\% dos animais após serem submetidos a herniorrafia padrão, sendo que $58 \%$ sofreram a técnica de transposição do músculo glúteo superficial e 12\% se submeteram à elevação do músculo obturador interno, desenvolveram infecção pós-operatória (SJOLLEMA et al., 1989). Em outra pesquisa, 13\% dos animais que foram submetidos a herniorrafia padrão e 58\% que se submeteram à transposição do músculo glúteo desenvolveram infecção pós-operatória (WEAVER et al., 1981).

Preconiza-se a realização da orquiectomia imediatamente após a herniorrafia, embora alguns autores duvidem do valor terapêutico da castração na ausência de uma prostatopatia concomitante (MANN et al., 1989). Por outro lado, pesquisas demonstram que animais castrados têm menor possibilidade de recidiva da hérnia perineal. Relata-se que o risco de recidiva em cães não castrados é 2,7 vezes maior que nos já castrados (WEAVER et al., 1981). 
III - MATERIAL E MÉTODO 


\section{MATERIAL E MÉTODO}

Partindo, então, do objetivo de verificar a eficiência do emprego da membrana biológica de pericárdio de eqüino na correção da hérnia perineal unilateral como reforço da reconstrução cirúrgica do diafragma pélvico, esta dissertação recorreu à análise comparativa de dois procedimentos cirúrgicos distintos durante a utilização da técnica de elevação do músculo obturador interno. No primeiro deles a cirurgia foi realizada sem a introdução da membrana e no segundo com a introdução da mesma. O material e o método empregados neste estudo estão descritos a seguir:

\subsection{MATERIAL}

Para a realização desta pesquisa, foram necessários: pacientes e equipamentos que estão discernidos conforme se sucede.

\subsubsection{Pacientes (animais utilizados)}

Foram utilizados 10 cães machos portadores de hérnia perineal unilateral esquerda ou direita, triados no Hospital Veterinário da Faculdade de Medicina Veterinária e Zootecnia da Universidade de São Paulo (HOVET/FMVZ/USP) e 
encaminhados ao Serviço de Cirurgia de Pequenos Animais do Departamento de Cirurgia (VCI - FMVZ/ USP), no período de julho de 2003 a janeiro de 2005.

\subsubsection{Critérios de Inclusão}

Consideraram-se cães de quaisquer idades, machos, com ou sem raça definida (CRD/SRD), e de cujo histórico houvesse sinais clínicos e exame físico de disquesia/ tenesmo, aumento de volume perineal unilateral, presença de enfraquecimento ou ruptura do diafragma pélvico à palpação retal, que levassem ao diagnóstico de hérnia perineal e que os proprietários aceitassem a intervenção cirúrgica e se comprometessem a respeitar os retornos pós-operatórios solicitados.

\subsubsection{Critérios de Exclusão}

Aqueles cães que além da hérnia perineal apresentassem concomitantemente desordens hormonais e tumorações abdominais ou de pele. Animais que apresentassem evidências de perda da integridade do diafragma pélvico bilateralmente, ou que já apresentassem enfraquecimento do referido diafragma contralateral ao já comprometido; ou aqueles em que não tenha sido possível o acompanhamento durante o período pós-operatório, pelo não cumprimento dos retornos solicitados. 
Este estudo foi submetido à avaliação e aprovado pela Comissão de Bioética da Faculdade de Medicina Veterinária e Zootecnia da Universidade de São Paulo (Protocolo n 307/2003).

\subsubsection{Equipamentos}

Os equipamentos relevantes como, material cirúrgico, material de sutura, membrana biológica, exames ultra - sonográfico e radiográfico são descritos abaixo.

\subsubsection{Material Cirúrgico}

Utilizou-se caixa cirúrgica padrão do Serviço de Cirurgia de Pequenos Animais, composta por: 1 pinça para anti-sepsia, 8 pinças Backaus, 4 pinças Allys, 10 pinças cirúrgicas hemostáticas de Kelly, 4 pinças hemostáticas Crille, 2 pinças anatômicas, 2 pinças dente de rato, 3 tesouras Hegar Mayo ponta fina e ponta romba , 2 afastadores de Farebeuf, 1 porta agulha Hegar Mayo, 1 cabo de bisturi no 3 e 1 cabo nº 4, lâmina de bisturi e 1 caixa de agulhas curvas pontas finas e triangulares. 


\subsubsection{Material de Sutura}

Valemo-nos de fios não absorvíveis, sintéticos (náilon) de numeração 2-0 para fechamento do plano muscular. Para realização da sutura de retalho do pericárdio de eqüino junto ao plano muscular perineal e também para o fechamento da pele foram utilizados fios não absorvíveis sintéticos (náilon) de numeração 3-0.

\subsubsection{Membrana Biológica}

Os sacos pericárdios de eqüino da raça Puro Sangue Inglês, foram coletados de animais cuja eutanásia era recente (até 6 horas) e cuja moléstia não era significativa do ponto de vista de comprometimento de órgãos vitais (fraturas ósseas), porém indicativas de eutanásia, lavadas em solução fisiológica a 0,9\% e conservadas em solução de glicerina a 98\%, em recipientes de vidro, onde permaneceram por período mínimo de 30 dias até que pudessem ser utilizadas. Quando utilizada, somente um pequeno fragmento de aproximadamente $5 \mathrm{~cm}$ de comprimento e largura, era retirado do conservante, lavado em solução fisiológica e posto em recipiente estéril contendo solução fisiológica de cloreto de sódio a 0,9 \%, para re-hidratação. O restante da membrana era recolocado na sua posição original, coberto por gaze e pelo conservante novamente. O frasco desta membrana somente era reaberto após período mínimo de 30 dias. 
3.1.4.4 Exame Ultra - sonográfico

Utilizou-se aparelho de ultra-sonografia dinâmica, bidimensional - modelo Cs 30-30 marca Tokimec, com transdutores eletrônicos convexos e lineares, variando de 5 a 7,5 MHz, de acordo com o porte do animal e o órgão a ser avaliado.

3.1.4.5 Exame Radiográfico

Para realização do referido exame foi empregado aparelho de Raios-X, modelo RT 500/125, marca Ray - Tec 500.

\subsection{MÉTODO}

Os métodos utilizados para obtenção e análise dos resultados estão descritos em seguida. 


\subsubsection{Exame Clínico}

Da anamnese efetuada, foram obtidos dados referentes ao tempo de evolução da hérnia perineal, desde o momento em que o proprietário a notou até o atendimento no HOVET/FMVZ/USP, seguido do relato dos sintomas mais freqüentemente observados pelo proprietário.

Em seguida o exame físico foi realizado, com a mensuração dos parâmetros clínicos: temperatura, consistência e tamanho dos linfonodos submandibulares, préescapulares e poplíteos, freqüências cardíaca e respiratória, tempo de preenchimento capilar (TPC), palpação digital externa do aumento de volume perineal para verificar-se a consistência e o provável conteúdo presente no saco herniário, palpação retal com a finalidade de auxiliar na avaliação do conteúdo do saco herniário e do reto.

A sensibilidade local ao toque foi determinada neste momento e considerou-se como pouco dolorosa quando a palpação digital externa e o toque retal eram realizados sem complicações; sensibilidade moderada ao permitir o exame, embora fosse possível perceber o desconforto e vocalização do animal; e sensibilidade severa onde o paciente relutava em permitir ser examinado.

Nos cães com obstrução urinária secundária à posição retrofletida da bexiga urinária, esta foi esvaziada por cateterização vesical ou cistocentese perineal seguido de sondagem uretral. Posteriormente, nesses casos, a sonda uretral foi fixada por meio de um ponto com fio cirúrgico inabsorvível e monofilamentoso (náilon ${ }^{1}$ ) próximo ao orifício do prepúcio ou pênis do animal, e o animal permaneceu com colar elisabetano e

\footnotetext{
${ }^{1}$ Ethicon ${ }^{\circledR}$ - fio de náilon cirúrgico inabsorvível e monofilamentoso - Johnson \& Johonson.
} 
antibioticoterapia (ampicilina $20 \mathrm{mg} / \mathrm{kg}$, a cada oito horas por administração oral ou a cada 24 horas por administração via subcutânea) até o momento da realização da herniorrafia.

\subsubsection{Exames Complementares}

Os exames solicitados antes do procedimento cirúrgico foram: ultra-sonografia, radiografias da região perineal e exame eletrocardiográfico, para verificar-se, respectivamente, o conteúdo da hérnia perineal e detectar alterações cardíacas que exigissem maior cuidado durante os transoperatório e pós-operatório. Realizaram-se, igualmente, exames laboratoriais tais como: análise sérica de uréia, creatinina e hemograma, aplicados de rotina no Serviço de Anestesia do Departamento de Cirurgia junto ao HOVET/FMVZ/USP.

\subsubsection{Interpretação do Exame Eletrocardiográfico}

Os pacientes foram encaminhados ao Serviço de Cardiologia do Departamento de Clínica Médica junto ao HOVET/FMVZ/USP, para avaliação cardíaca. Foram realizados os exames eletrocardiogáfico e quando necessário, o exame ecocardiográfico do paciente.

\footnotetext{
${ }^{2}$ Optacilin 500mg injetável ${ }^{\circledR}$ - Ampicilinas benzatina e sódica, frasco ampola - Byk.
} 
Todos os pacientes cardiopatas que foram submetidos à intervenção cirúrgica estavam com a doença cardíaca sob controle durante os períodos pré e transoperatório e tiveram o aval do Serviço de Cardiologia para a realização da intervenção cirúrgica. Alguns pacientes necessitaram de acompanhamento junto ao Serviço de Cardiologia posteriormente ao ato operatório.

\subsubsection{Interpretação dos Exames Laboratoriais}

Os exames solicitados comuns a todos os pacientes foram o de hemograma e função renal. Devido a grande parte dos pacientes terem já tido contato anterior com carrapatos e devido ao tempo prolongado do ato operatório e ao sítio cirúrgico ricamente vascularizado, optou-se também pela mensuração de plaquetas em todos os animais. Na presença de doença infecto-contagiosa ou parasitária, evidenciadas pelo hemograma (babesiose e erlichiose confirmadas ou hemograma sugestivo de hemoparasitose ou parasitose), os pacientes eram encaminhados ao Serviço de Clínica Médica de Pequenos Animais do Departamento de Clínica Médica junto ao HOVET/FMVZ/USP e retornando ao Serviço de Cirurgia de Pequenos Animais após a liberação do paciente pelo referido Serviço. Os resultados do hemograma e da função renal (uréia e creatinina) foram avaliados durante o retorno do exame clínico. Foram realizadas as leituras dos dados, pelo Serviço de Laboratório Clínico do Departamento de Clínica Médica da FMVZ/USP. As intervenções cirúrgicas foram marcadas, no momento que as alterações de hemograma e bioquímica mostravam-se compatíveis com o ato operatório. 


\subsubsection{Interpretação dos Exames de Imagem}

Os animais foram submetidos a exames radiográficos simples e contrastados pré-operatórios da região perineal, posições ventro-dorsal e latero-lateral. Foram colocados em decúbito lateral direito ou esquerdo com cateterização uretral com sonda flexível através da uretra peniana, de numeração compatível ao porte do paciente. Após a sondagem uretral, o contraste Urografina $292^{3}$ diluído em solução fisiológica de cloreto de sódio a $0,9 \%{ }^{4}$ na proporção $1: 2$ foi introduzido no interior da sonda uretral, pela uretra até que o preenchimento da vesícula urinária pudesse ser visualizado.

Igualmente, exames ultra-sonográficos pré-operatórios foram realizados nos pacientes a serem submetidos à herniorrafia perineal. Após a tricotomia do abdômen e períneo, os pacientes permaneceram em decúbito dorsal para a realização inicial do exame do abdômen. Em seguida, colocados em decúbito lateral para avaliação das estruturas do períneo.

As avaliações radiográficas e ultra-sonográficas foram realizadas pelo Serviço de Diagnóstico por Imagem do Departamento de Cirurgia junto ao HOVET/FMVZ/USP.

\footnotetext{
${ }^{3}$ Urografina 292/370® - amidotrizoato sódico e meglumínico - Schering do Brasil.

${ }^{4}$ Solução fisiológica de cloreto de sódio a $0,9 \%$.
} 


\subsubsection{Período Pré-Operatório}

Os animais permanecem em jejum prévio alimentar por 12 horas e água por oito horas. A higienização da pele e pelagem do animal, com sabonete anti-séptico (soapex ${ }^{5}{ }^{\circledR}$ ) foi solicitada e providenciada pelo proprietário.

Os antibióticos utilizados foram ampicilina ${ }^{6}$ na dosagem de $20 \mathrm{mg} / \mathrm{kg}$ a cada 24 horas por via subcutânea ou em intervalos de oito horas por via oral, associada ao metronidazol $^{7}$ na dosagem de $15 \mathrm{mg} / \mathrm{kg}$ a cada 12 horas por via oral. A administração de ampicilina ${ }^{6}$ por via subcutânea ocorreu imediatamente após a aplicação de medicação pré-anestésica.

Os animais foram avaliados e anestesiados segundo protocolos estabelecidos pelo Serviço de Anestesia do Departamento de Cirurgia junto ao HOVET/FMVZ/USP, de acordo com a tabela da ASA (American Society Anaesthesia 1 a 5).

Foi realizada “tricotomia” da região perineal, pré-escrotal e escrotal. Neste momento, com o paciente sob efeito de sedativos (acepromazina ${ }^{8}$ associada com meperidina ${ }^{9}$ ou morfina ${ }^{10}$ ), foi realizada a remoção manual das fezes presente na ampola retal.

\footnotetext{
${ }^{5}$ Soapex sabonete ${ }^{\circledR}$ - sabonete anti-séptico a base de triclosan - Darrow.

${ }^{6}$ Optacilin 500 mg injetável ${ }^{\circledR}$ - Ampicilinas benzatina e sódica, frasco ampola - Byk.

${ }^{7}$ Flagyl comprimidos de $400 \mathrm{mg}, 250 \mathrm{mg}$ e pediátrico ${ }^{\circledR}$ - metronidazol - Rhodia.

${ }^{8}$ Acepran $0,2 \%$ e $1 \%{ }^{\circledR}$ - acepromazina - Univet,

${ }^{9}$ Dolantina ampola $100 \mathrm{mg}{ }^{\circledR}$ - meperidina - Hoechst Marion Roussel.

${ }^{10}$ Dimorf SP ampola de 5 e 10 mg ${ }^{\circledR}$ - sulfato de morfina - Cristália.
} 


\subsubsection{Procedimento Cirúrgico}

Os animais foram divididos em dois grupos (GI e GII) com cinco representantes em cada um. Ao primeiro grupo (GI) foi aplicada, para correção da hérnia perineal, somente a herniorrafia por elevação do músculo obturador interno conforme a técnica descrita por Orsher e Johnston (1985) e modificada por Sjollema (1989). Quanto ao segundo grupo (GII), os animais após ter o diafragma pélvico já reconstituído pela referida técnica de elevação do músculo obturador interno, este foi reforçado com enxerto heterotópico e xenólogo de retalho de membrana biológica de pericárdio de eqüino da raça Puro Sangue Inglês conservado em glicerina a 98\% e armazenado por no mínimo 30 dias.

\subsubsection{Técnica Operatória}

Tanto nos grupos GI e GII, os cães foram posicionados em decúbito esternal com acolchoamento na região inguinal que esteve em contato com a mesa para evitar pressão sobre os nervos femorais. A cauda foi flexionada craniodorsalmente e atada sob pressão para melhorar a exposição do músculo coccígeo. A mesa cirúrgica foi colocada em posição de Trendelenburger a fim de se elevar a pelve do animal (Apêndices G a I, Figuras 1 a 14). Para evitar o refluxo de fezes líquidas e para facilitar a localização do reto durante o procedimento cirúrgico, um cilindro de atadura de gaze foi introduzido em seu lúmen antes da realização da bolsa de tabaco (Apêndice I, Figura 15). Em 
seguida realizou-se a referida sutura em com fio inaborvível monofilamento de náilon 20 (Apêndice I, Figura 16). Todos os cães permaneceram com sonda uretral durante o ato operatório.

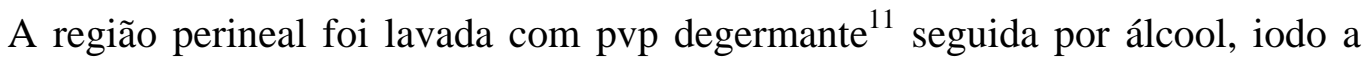
$2 \%{ }^{12}$ e álcool para finalizar a anti-sepsia.

Uma incisão curvilínea com aproximadamente 4 a 7 cm foi realizada sobre a pele, do maior eixo da tumoração, estendendo-se da base da cauda em direção a linha mediana, ventral ao ânus (Apêndice I, Figura 17).

Os vasos subcutâneos foram ligados com fio de náilon monofilamento 4-0, e os tecidos subcutâneo e adiposo divulsionados até se alcançar o músculo retococcígeo e os saco herniário. O músculo retococcígeo foi preservado, enquanto que o saco herniário foi delicadamente rompido através de divulsão digital romba. O conteúdo herniado neste momento foi exposto (Apêndices I e J, Figuras 18 a 20).

As vísceras foram reduzidas à cavidade pélvica e abdominal por pressão cranial com auxílio de gaze fixada na extremidade de uma pinça hemostática, com cuidado para evitar lesão da artéria e da veia pudendas internas assim como do nervo pudendo, todos eles localizados na porção ventral do saco herniário (Apêndice G, Figura 2).

A identificação dos músculos esfíncter externo do ânus, coccígeo, obturador interno e elevador do ânus pôde ser realizada neste momento. Conseguiu-se neste instante avaliar o grau de atrofia dos referidos músculos, de acordo com os seguintes parâmetros: ausência de atrofia - 4 (o músculo mostrava-se íntegro); atrofia discreta - 3 (músculo de volume subjetivamente menor que o usual); atrofia moderada - 2 (músculo de volume visivelmente menor que geralmente observado) e atrofia severa -1 (pouca quantidade ou ausência da musculatura).

\footnotetext{
${ }^{11}$ PVPI solução® - iodopolividona - Miyako do Brasil Ind. e Com.ltda.

${ }^{12}$ Iodo 2\% solução® - Myako do Brasil Ind. e Com.ltda.
} 
O músculo obturador interno foi elevado do assoalho isquiático pelo bordo caudal, com auxílio de bisturi. O fechamento do anel herniário iniciou-se pela colocação de suturas com fio de náilon monofilamento 2-0 e agulha 4/8 traumática, incorporando os músculos coccígeo e esfíncter externo do ânus em suas porções dorsais (Apêndice G, Figura 3). Pontos de sutura foram apostos incluindo o bordo caudolateral do músculo obturador interno e parte ventral do músculo coccígeo. A borda caudomedial do músculo obturador interno foi suturada à porção mais ventral do músculo esfíncter externo do ânus através de outros pontos de sutura. As suturas foram inseridas, porém não fixadas com nó de cirurgião, até que todo o planejamento da correção tivesse sido concluído (Apêndice G, Figuras 4 e 5).

Nos animais pertencentes ao segundo grupo (GII) foi aplicado o enxerto heterotópico e xenólogo já referido sobre o diafragma pélvico fixando-o com pontos de sutura simples com náilon monofilamento 3-0 (Apêndices I a J, Figuras 6 a 21). A membrana permaneceu por aproximadamente dez minutos sob imersão e em seguida estendida sobre compressa estéril, e, posteriormente, preparada em forma de retalho no tamanho suficiente para cobrir a região do diafragma pélvico, que fora anteriormente reconstruído. Logo em seguida embebida em ampicilina ${ }^{1}$ na concentração de $100 \mathrm{mg} / \mathrm{ml}$ e suturada junto ao plano muscular (Apêndice L, Figuras 29 a 33).

Em ambos os grupos o tecido subcutâneo foi aproximado por sutura em ponto simples separado com náilon monofilamento 3-0 (totalizando três a quatro suturas em PSS) e a pele suturada com fio de náilon monofilamento 3-0 através de pontos simples e separado (Apêndice J, Figura 22).

Todos os cães foram submetidos à orquiectomia por incisão pré-escrotal através da técnica clássica e com a permissão do proprietário. 
Em seguida a sutura em bolsa de tabaco e o material utilizado para 0 tamponamento retal foram cuidadosamente removidos, a fim de evitar-se a contaminação da ferida cirúrgica. A sustentação promovida pela sutura e a possibilidade de algum ponto da sutura terem adentrado o lúmen retal foram verificados por palpação retal.

\subsubsection{Período Pós-Operatório}

Os cães foram liberados, pelo cirurgião e anestesista para o domicílio no mesmo dia do procedimento cirúrgico, após recuperação anestésica com orientação de se lavar a ferida cirúrgica diariamente com sabão a base de $\operatorname{triclosan}^{13}$ três a quatro vezes ao dia e sempre após o animal defecar. Foram mantidos os antibióticos (metronidazol ${ }^{14}$ e ampicilina ${ }^{15}$ ) por 10 dias, associado com ketoprofeno ${ }^{16}$ como antiinflamatório na dose de $1 \mathrm{mg} / \mathrm{kg}$ uma vez ao dia por quatro dias. Os pontos de sutura foram retirados quando possível a partir de sete a 17 dias do período pós-operatório.

Os exames radiográficos e ultra-sonográficos, segundo a técnica descrita antes do procedimento cirúrgico também o foram realizados no período pós-operatório tardio (30, 60 e 90 dias), no intuito de comparação e averiguação do posicionamento anatômico das vísceras, bem como estudo do cólon e reto.

\footnotetext{
${ }^{13}$ Soapex sabonete ${ }^{\circledR}$ - sabonete anti-séptico a base de triclosan - Darrow

${ }^{14}$ Flagyl comprimidos de $400 \mathrm{mg}, 250$ mg e pediátrico ${ }^{\circledR}$ - metronidazol - Rhodia.

${ }^{15}$ Optacilin 500 mg injetável ${ }^{\circledR}$ - Ampicilinas benzatina e sódica, frasco ampola - Byk.

${ }^{16}$ Ketofen comprimidos de 5 e 20 mg ${ }^{\circledR}$ - ketoprofeno - Merial.
} 


\subsubsection{Análise dos Resultados}

A avaliação pós-operatória foi realizada através da anamnese verificando-se a ocorrência de facilidade ou dificuldade de evacuação, presença ou não de constipação leve, moderada ou severa, incontinência fecal e/ ou urinária e pela observação clínica da região perineal onde se verificou a resistência do diafragma reconstruído (se estava firme ou flácido), edema local, modificação da coloração de pele, deiscência de pontos de sutura da pele e presença ou não de contaminação.

A evacuação foi determinada conforme o escore previamente definido: 0 sem dificuldade; 1 com dificuldade; 2 com dificuldade e com esforço; 3 com dificuldade, com esforço e com dor e 4 impossibilidade de evacuação.

O toque retal possibilitou verificar a ocorrência de desvio, saculações no reto, penetração de sutura e também a integridade e firmeza do diafragma pélvico.

A ferida cirúrgica considerada infectada durante o procedimento cirúrgico, caracterizou-se por drenagem de material purulento, por meio de fístula perianal, por até três a quatro dias de pós-operatório. Após este período, considerou-se ferida cirúrgica contaminada durante o período de pós-operatório, devido à lambedura constante do animal no local operado e a limpeza inadequada da região.

Considerou-se incontinência fecal, perda do controle do ato de defecar, expulsão de conteúdo fecal constante ao andar ou até mesmo no esforço ao latir.

Caracterizou-se como incontinência urinária a eliminação de urina constante ou após excitamento do animal. Considerou-se também como incontinência urinária a micção sem controle, mesmo enquanto animal encontrava-se dormindo. 
Os animais retornaram dentre um período de 24 a 48 horas, sete e quinze dias após o procedimento cirúrgico para avaliação comparativa. Retornaram, novamente, com 30, 60 a 90 dias de pós-operatório para avaliação do posicionamento das vísceras em relação ao diafragma pélvico (fossa ísquio-retal) avaliados por meio de ultra-som e aos 90 dias também se realizou radiografia simples e contrastada da região perineal além do exame clínico. 
IV - RESULTADOS 


\section{$4 \quad$ RESULTADOS}

A análise comparativa apresentada anteriormente, bem como o método e o material utilizado produziram, nos pacientes observados, os resultados apresentados a seguir.

\subsection{PACIENTES}

A idade dos pacientes tratados situou-se entre seis e 16 anos, sendo a média observada de dez anos e três meses. Os animais apresentaram pesos entre 3,4 kg a 19 kg, sendo a média de 8,3 kg. As raças observadas durante este estudo clínico foram: Poodle ( $\left.n^{\circ} 1 ; 3 ; 5-30 \%\right)$, SRD ( $\left.n^{\circ} 7 ; 8-20 \%\right)$, Yorkshire $\left(n^{\circ} 6-10 \%\right)$, Fox Paulistinha (n $9-10 \%$ ), Lhasa Apso (n $\left.n^{\circ} 2-10 \%\right)$, Pinscher (n $4-10 \%$ ) e Mestiço poodle ( $\mathrm{n}^{\mathrm{o}} 10$ - 10\%), conforme demonstrado no apêndice A, quadro 1.

\subsection{AVALIAÇÃO CLÍNICA PRÉ - OPERATÓRIA}

Dos animais que participaram do estudo, a metade deles $\left(n^{\circ} 1 ; 3 ; 4 ; 7 ; 10-\right.$ 50\%), tiveram o diagnóstico de hérnia perineal unilateral efetuado por médico veterinário em clínica particular e foram encaminhados para tratamento no 
HOVET/FMVZ/USP. Dentre os animais encaminhados por colega (50\%), todos (100\%) já vinham sendo medicados com laxantes e submetidos a esvaziamento retal manual. Dois destes animais ( $\left.\mathrm{n}^{\circ} 7 ; 10-40 \%\right)$, que foram anteriormente medicados, não tiveram sua dieta alimentar modificada. Aos proprietários dos animais restantes ( $\mathrm{n}^{0} 1 ; 3 ; 4$ 60\%) foi recomendado manter-se dieta com ração semi-úmida (Frolic®) ou comida caseira. O tempo ocorrido entre o diagnóstico da paratopia em clínica particular até o tratamento cirúrgico no HOVET variou de um mês até 12 meses, com média de cinco meses.

Os outros animais pertencentes ao estudo $\left(\mathrm{n}^{\circ} 2 ; 5 ; 6 ; 8 ; 9-50 \%\right)$, tiveram o diagnóstico de hérnia perineal realizada no HOVET/FMVZ/USP. Estes animais encontravam-se sem medicação para a facilitação do ato de evacuar no momento do diagnóstico no Hospital Veterinário da FMVZ. Três animais (nº 2; $8 ; 9-60 \%$ ) recebiam, como dieta, ração seca $\left(\right.$ Bonzo ${ }^{\circledR}$, Pedigree ${ }^{\circledR}$, Proplan $\left.{ }^{\circledR}\right)$ misturado com comida caseira (nº 8; 9 - 40\%) ou com ração úmida (ração em lata Pedigree $\left.{ }^{\circledR}\right)\left(n^{\circ} 2\right.$ 20\%), um (nº 5 - 20\%) com ração seca, somente (Pedigree $\left.{ }^{\circledR}\right)$. Por fim um animal (nº 6 20\%) era alimentado à base de ração semi-úmida (Frolic®). O período no qual o proprietário observou alteração no aspecto da região perineal e procurou ajuda veterinária ao HOVET/FMVZ/USP variou de três dias até 12 meses, com média de quatro meses.

O tempo de evolução dos dez casos de hérnias perineais unilaterais deste estudo variou de três dias até 12 meses, do momento do diagnóstico até o tratamento, com média de 4,3 meses.

Nenhum dos animais deste estudo havia sido submetido tratamento prévio cirúrgico, para correção da paratopia. 
Os sintomas relativos ao sistema digestório, observados pelos proprietários, foram de: hiporexia ( $\left.n^{\circ} 5 ; 9 ; 10-30 \%\right)$, polifagia $(4-10 \%)$, disquesia $\left(n^{\circ} 1 ; 2 ; 4 ; 5 ; 6\right.$; 7; 8; 9; $10-90 \%)$, tenesmo $\left(\mathrm{n}^{\mathrm{o}} 1 ; 5 ; 7 ; 9-40 \%\right)$, prurido anal $\left(\mathrm{n}^{\mathrm{o}} 6-10 \%\right)$, emese $\left(\mathrm{n}^{\mathrm{o}}\right.$ 2; 8; $10-30 \%)$, fezes pastosas e em formato de fita (n $5 ; 6 ; 7 ; 8 ; 9 ; 10-60 \%$ ) ou, esporadicamente, em pedaços ressecados de consistência dura ( $\left.n^{\circ} 1 ; 2 ; 3 ; 4-40 \%\right)$ e com estrias de sangue vivo ( $\left.n^{\circ} 5 ; 8 ; 9-30 \%\right)$.

O período de observação da disquesia por parte do proprietário variou de cinco dias até 24 meses, com média de 5,4 meses. Já, o período de observação de tenesmo oscilou entre cinco dias até 90 dias, com média de 23,4 dias. O escore de evacuação pontuado pelo proprietário foram os seguintes: 0 ( $\left.\mathrm{n}^{\mathrm{o}} 3-10 \%\right), 1$ ( $\left.\mathrm{n}^{\mathrm{o}} 5-10 \%\right), 2\left(\mathrm{n}^{\mathrm{o}} 2\right.$; $4 ; 6 ; 7 ; 10-50 \%)$ e $3\left(n^{\circ} 1 ; 8 ; 9-30 \%\right)$. Os dados referentes à evolução, sintomas observados, aspecto das fezes e escore de evacuação, encontram-se no apêndice B, quadro 2.

Outros sintomas observados pelos proprietários foram: urina de coloração escura ( $\left.n^{\circ} 2 ; 10-20 \%\right)$, disúria ( $\left.n^{\circ} 5-10 \%\right)$, incontinência urinária ( $n^{\circ} 6-10 \%$ ), polidipsia (n 9 - 10\%), diminuição da libido (nº 6; 10 - 20\%), hábito de levantar a perna para urinar ausente ( $\left.n^{\circ} 4-10 \%\right)$ e demarcar território com maior freqüência (n ${ }^{\circ} 10$ - 10\%).

Durante o exame clínico os sinais observados foram de: mucosas oculares congestas ( $\left.n^{\circ} 1 ; 4-20 \%\right)$, hiperêmicas ( $n^{\circ} 3 ; 9$ - 20\%) e hipocorada ( $n^{\circ} 7$ 10\%), hipertermia discreta ( $\left.n^{\circ} 3-10 \%\right)$, não possibilidade de mensuração da temperatura retal devido à dor local ( $\left.\mathrm{n}^{\circ} 2 ; 7 ; 10-30 \%\right)$, abdômen tenso $\left(\mathrm{n}^{\circ} 1 ; 6 ; 9-30 \%\right)$, obesidade $\left(\mathrm{n}^{\mathrm{o}}\right.$ 4 -10\%), presença de alteração no ritmo e/ou evidência de sopro cardíaco durante á auscultação cardíaca com fonendoscópio (nº 4; 5; 8; 9; 10 - 50\%). 
Dentre os animais observados, apenas $1\left(\mathrm{n}^{0} 3\right)$ apresentou testículo ectópico em canal inguinal externo (testículo esquerdo), com discrepância entre os tamanhos (esquerdo menor que o direito), sendo o testículo direito normal.

\subsubsection{Aspecto Clínico da Hérnia Perineal}

Todos os cães apresentaram aumento de volume na região perineal direitos $\left(n^{\circ} 1\right.$; 3; 5; 6; 7; 9 - 60\%) ou esquerda $\left(n^{\circ} 2 ; 4 ; 8 ; 10-40 \%\right)$, de consistência variando entre mista - área de consistência mole entremeada com área de consistência firme - $\left(\mathrm{n}^{\circ} 1 ; 2\right.$; 4; 6 - 40\%); mole ( $n^{\circ}$ 3; 5; 9 - 30\%) e firme $\left(n^{\circ} 7 ; 8 ; 9-30 \%\right)$. O aumento de volume na região perineal, verificado por meio de taxe, caracterizava-se como redutível ( $\mathrm{n}^{\circ} 1 ; 3$; 4; 5; 6; 7; 8; 9; 10 - 90\%). Porém, em um paciente ( ${ }^{\circ} 2-10 \%$ ), a hérnia perineal encontrava-se irredutível, onde à pressão manual, o conteúdo não pôde ser reposicionado na cavidade abdominal.

O conteúdo provável que pôde ser percebido pela palpação do aumento de volume foi de: próstata ( $\mathrm{n}^{\mathrm{o}} 1 ; 2 ; 4 ; 5 ; 6 ; 7 ; 9$ - 70\%), vesícula urinária ( $\mathrm{n}^{\circ} 2$ - 10\%), compactação fecal discreta (no $1 ; 2 ; 4-30 \%)$, moderada $\left(n^{\circ} 7 ; 8-20 \%\right)$ e severa $\left(n^{\circ} 10\right.$ - 10\%), com necessidade de eliminação manual das fezes da ampola retal em paciente sob efeito de sedação.

A sensibilidade local ao toque mostrou-se pouco dolorosa $\left(n^{0} 2 ; 3 ; 4 ; 6 ; 8\right.$ $50 \%$ ) e o exame era realizado sem complicações; com sensibilidade moderada ( $\mathrm{n}^{\circ}$ 5; 9 20\%), mas cujo animal permitiu o exame e, sensibilidade severa ( $\mathrm{n}^{\mathrm{o}} 1 ; 7 ; 10-10 \%$ ), onde o paciente relutava em permitir ser examinado. 
Pelo toque retal, pôde-se notar: desvio de reto ipsilateral ao aumento de volume perineal ( $\left.n^{\circ} 2 ; 3 ; 4 ; 6 ; 7 ; 8-60 \%\right)$, aumento do diâmetro do lume retal (no 4; 6; $9 ; 10$ 40\%), próstata com sensibilidade e aumentada de volume (nº 4; 7; $1-30 \%$ ). Não foi possível avaliar a próstata em alguns animais $\left(\mathrm{n}^{\circ} 3 ; 6 ; 10\right.$ - 30\%) por estar localizada em abdômen e/ou pela compactação fecal. Aspectos relacionados à consistência da região perineal e seu conteúdo provável, detectado por palpação, estão descritos no apêndice C, quadro 3.

4.3 AVALIAÇÃO DOS EXAMES LABORATORIAIS (hemograma, função renal)

Dentre os animais estudados, alguns ( $\left.\mathrm{n}^{0} 1 ; 3 ; 4 ; 9-40 \%\right)$ tiveram, conforme a necessidade, avaliação da bioquímica sérica total (função hepática).

O exame de hemograma demonstrou ser útil para a detecção de anemias regenerativas $\left(n^{\circ} 7-10 \%\right)$, leucocitose neutrofílica discreta $\left(n^{\circ} 2 ; 4 ; 5 ; 8-40 \%\right)$, evidenciando processo infeccioso.

4.4. AVALIAÇÃO DOS EXAMES PRÉ - OPERATÓRIOS DE IMAGEM ULTRA SONOGRÁFICA

Pelo ultra-som foi possível identificar as estruturas presentes no aumento de volume perineal (100\%). As estruturas identificadas foram: próstata $\left(\mathrm{n}^{0}\right.$ 1;3;4;5;6;7;9 - 
$70 \%)$, vesícula urinária ou parte dela $\left(\mathrm{n}^{\circ} 3 ; 5 ; 7 ; 9-40 \%\right)$, segmento de alça intestinal $\left(\mathrm{n}^{\circ}\right.$ 1;2;4;6;7;8;9,10 - 80\%) com conteúdo produtor de sombra acústica no seu interior fezes ( $n^{\circ}$ 6;7;8;10 - 40\%), líquido livre no saco heniário ( $n^{\circ} 1 ; 2 ; 3-30 \%$ ). Conforme observado ao apêndice C, quadro 3.

Outras alterações foram possíveis de serem detectadas pelo exame ultrasonográfico no trato gênito urinário, tais como: rins com ecogenicidade elevada $\left(\mathrm{n}^{0} 2\right.$; 4; $8-30 \%$ ) com contornos irregulares ( $n^{\circ} 4 ; 9-20 \%$ ), pelve dilatada ( $n^{\circ} 4 ; 9-20 \%$ ), ureter dilatado ( $n^{\circ} 9$-10\%) e perda da definição córtico - medular (n 4 - 10\%). Observou-se, também, deslocamento caudal da vesícula urinária ( $n^{\circ} 1 ; 4 ; 7$ - 30\%), localização ectópica da vesícula urinária ( $n^{\circ}$ 3; 5; 9 - 30\%), espessamento e irregularidade de parede da mucosa vesical ( $\left.{ }^{\circ} 4 ; 5 ; 6 ; 9-40 \%\right)$. As alterações de forma e do parênquima da próstata foram aferidas por este exame. Foi possível detectar localização ectópica ( $\mathrm{n}^{\circ} 1 ; 3 ; 4 ; 5 ; 6 ; 7 ; 9$ - 70\%), aumento de tamanho $\left(\mathrm{n}^{\circ} 2 ; 4 ; 5 ; 7 ; 8\right.$ $50 \%)$, irregularidade do parênquima $\left(\mathrm{n}^{\circ} 2 ; 4 ; 5 ; 8 ; 10\right.$ - 50\%), com presença de cistos anecóicos de variados tamanhos $\left(n^{\circ} 2 ; 4 ; 5 ; 8 ; 10\right.$ - 50\%). O diâmetro da próstata medido durante o exame variou de $1,8 \mathrm{~cm}$ a $4,5 \mathrm{~cm}$, com média de $3,0 \mathrm{~cm}$. Apenas quatro dos dez animais ( $n^{0} 1 ; 3 ; 6 ; 9$ - 40\%), não apresentaram nenhuma alteração no tamanho ou parênquima ao exame de ultra-som, embora a próstata se localizasse no aumento de volume perineal (localização ectópica).

Alguns pacientes apresentaram em um dos seus testículos, formações nodulares (n ${ }^{\circ}$; 9 - 20\%), parênquima heterogêneo $\left(n^{\circ}\right.$ 2; 8; 9 - 30\%) e localização ectópica inguinal $\left(n^{\circ} 3-10 \%\right)$.

Ainda, como achados ultra-sonográficos foram constatados: esplenomegalia $\left(\mathrm{n}^{\circ}\right.$ 2; 8 - 20\%), nódulo hipoecóico pequeno no parênquima (nº 5; 8 - 20\%), hepatomegalia 
$\left(n^{0} 4-10 \%\right)$, aumento discreto e levemente irregular no pólo caudal de uma das adrenais (n $4-10 \%)$.

\subsection{VALIAÇÃO DOS EXAMES PRÉ - OPERATÓRIOS DE IMAGEM RADIOGRÁFICA}

Os exames radiográficos pré-operatórios foram realizados em quase todos os pacientes ( $\mathrm{n}^{\circ} 1 ; 2 ; 3 ; 5 ; 6 ; 7 ; 8 ; 9 ; 10$ - 90\%), com exceção de um paciente de dezesseis anos de idade $\left(\mathrm{n}^{\circ} 4\right)$, devido à relutância do proprietário em submeter o animal a mais estresse. Cumpre assinalar que o exame radiográfico deste animal em questão foi obtido no período pós-operatório, com o consentimento do proprietário, visto o bom andamento da correção cirúrgica.

O exame radiográfico simples demonstrou: vesícula urinária deslocada caudalmente ( $\left.\mathrm{n}^{\circ} 1 ; 2 ; 3 ; 6-44 \%\right)$ e contorno pouco definido $\left(\mathrm{n}^{\circ} 3 ; 7 ; 8-33 \%\right)$.

O aumento de volume perineal foi observado em quase todos os animais $\left(\mathrm{n}^{\mathrm{o}} 1 ; 2\right.$; 5; 7; 9; 10 - 66\%) com conteúdo de radiopacidade água (nº 5; 9 - 22\%), heterogêneo fecal (n $2 ; 7 ; 10-33 \%)$ ou gasoso $\left(n^{\circ} 1-11 \%\right)$.

Dos animais com alterações em coluna vertebral observou-se à radiografia simples: alterações em coluna lombar $\left(n^{\circ} 1 ; 3 ; 6 ; 9-44 \%\right)$ ou lombo sacra $\left(n^{\circ} 3 ; 7 ; 10\right.$; 1; 9 - 55\%), como diminuição do espaço intervertebral ( ${ }^{\circ} 1 ; 3 ; 6 ; 9$ - 66\%), osteofito ventral ( $\left.n^{\circ} 7-16 \%\right)$ e osteofito anquilosante $\left(n^{\circ} 1 ; 8 ; 10-50 \%\right)$. Os principais segmentos de vértebras afetadas foram L3 -L4 (nº 6 - 16\%), L7-S1 (n ${ }^{\circ}$ 1; 7; 8; 10 66\%), L4-L5 (n 9 - 16\%), T13-L1 ( $\left.n^{\circ} 1-16 \%\right)$, vértebras coccígeas $2^{\mathrm{a}} .3^{\mathrm{a}} .4^{\mathrm{a}}$ e $5^{\mathrm{a}}\left(\mathrm{n}^{\mathrm{o}} 3\right.$ 
- $16 \%$ ). Somente dois animais dentre os nove examinados ( $\mathrm{n}^{\circ} 5 ; 2-22 \%$ ), não apresentaram alterações dignas de nota em coluna vertebral.

O segundo exame radiográfico realizado, a uretrocistografia, permitiu visualização mais acurada: deslocamento da vesícula urinária para canal pélvico ( ${ }^{0} 1$; 2; 3; $6 ; 7$ - 55\%), deslocamento cranial para região mesogástrica $\left(n^{\circ} 8-11 \%\right)$ ou da vesícula urinária retrofletida para o aumento de volume perineal ( $n^{\circ} 5 ; 9-22 \%$ ), irregularidade em superfície de parede da mucosa vesical ( $\left.n^{\circ} 1 ; 5 ; 6-33 \%\right)$ e presença de divertículo em pólo cranial de vesícula urinária ( $n^{\circ} 6$ - 11\%), deslocamento caudal da uretra prostática para o conteúdo herniado (nº 1; 2; 3; 5; 6; 8; 10 - 77\%), dilatação da uretra prostática ( $\left.{ }^{\circ} 7-11 \%\right)$, impregnação dos canalículos prostáticos $\left(n^{\circ} 1 ; 2 ; 5 ; 8\right.$ 44\%), próstata ectópica em conteúdo herniado ( $\left.\mathrm{n}^{\circ} 1 ; 2 ; 5 ; 7-44 \%\right)$, deslocamento cranial da próstata para região hipogástrica $\left(n^{\circ} 8-11 \%\right)$, aumento de tamanho da próstata (nº 8 - 11\%). Em alguns pacientes, a delimitação do contorno da próstata, não foi adequado (n $1 ; 3 ; 6 ; 7 ; 9-55 \%$ ), conforme descrito no apêndice C, quadro 3.

\subsection{PROCEDIMENTO ANESTÉSICO}

O protocolo estipulado pelo Serviço de Anestesia do Departamento de Cirurgia foi eficiente para assegurar boa analgesia ao procedimento cirúrgico, em geral, e relaxamento da musculatura envolvida no processo. Evisceração, que poderia atrapalhar o procedimento, não foi observada. Os pacientes foram enquadrados pelo Serviço de Anestesia em Pacientes ASA 2 (no $1 ; 2 ; 3 ; 5 ; 6 ; 7 ; 8 ; 10$ - 80\%) e 3 (nº 4; 9 - 20\%). 


\subsection{TÉCNICA CIRÚRGICA}

A técnica utilizada foi realizada, sem intercorrências, tendo as etapas propostas sidos cumpridas. A técnica exigiu habilidade manual moderada e "paciência” para a realização das suturas no plano muscular e da membrana, perfeitamente esticada e sem dobras, ao plano muscular já suturado anteriormente.

Os pacientes foram divididos em dois grupos neste momento (Grupo I e Grupo II) e a seguir os animais foram submetidos à orquiectomia.

O tempo cirúrgico para realização da orquiectomia e herniorrafia variou para o Grupo I de 100 minutos a 150 minutos, com média de 120 minutos. Para o Grupo II, este tempo cirúrgico mostrou-se de 85 minutos a 180 minutos, com média de 138 minutos.

Em seguida os animais foram posicionados em decúbito ventral e submetidos à herniorrafia proposta.

O conteúdo herniado encontrado durante o procedimento cirúrgico foi gordura retroperineal ( $\mathrm{n}^{\mathrm{0}} 1 ; 2 ; 4 ; 5 ; 6 ; 8 ; 9 ; 10$ - 80\%), epíplon ( $\mathrm{n}^{\circ}$ 3; 7; 9; 10 -40\%), próstata $\left(n^{\circ} 1 ; 4 ; 5 ; 6 ; 9-50 \%\right)$, vesícula urinária $\left(n^{\circ} 5 ; 3 ; 9-30 \%\right)$, divertículo retal $\left(n^{\circ} 10-\right.$ 10\%), cistos, aderências e fibrose ( $\left.n^{\circ} 2-10 \%\right)$, conforme consta no apêndice C, quadro 3.

Os músculos da região perineal apresentaram graus variáveis de atrofia. Durante o transoperatório observou-se o músculo coccígeo em atrofia discreta $\left(\mathrm{n}^{\circ} 1 ; 2 ; 6 ; 8 ; 10\right.$ $50 \%)$, moderada $\left(n^{\circ} 3 ; 4 ; 5-30 \%\right)$ e atrofia ausente (n $\left.{ }^{\circ} 7 ; 9-20 \%\right)$; o músculo elevador do ânus em atrofia discreta ( $\left.n^{\circ} 7-10 \%\right)$, moderada ( $\left.{ }^{\circ} 4 ; 6 ; 8 ; 10-40 \%\right)$, severa $\left(\mathrm{n}^{\circ} 1 ; 2 ; 3 ; 5 ; 9-50 \%\right)$; o músculo esfíncter anal externo em atrofia discreta $\left(\mathrm{n}^{\circ}\right.$ 
2; 3; 6; $10-40 \%)$, moderada $\left(n^{\circ} 8 ; 9-20 \%\right)$, severa $\left(n^{\circ} 1-10 \%\right)$ e atrofia ausente $\left(n^{\circ}\right.$ 4; 5; 7 - 30\%); o músculo obturador interno em atrofia discreta $\left(n^{\circ} 2 ; 4-20 \%\right)$, moderada ( $\left.n^{\circ} 1-10 \%\right)$ e atrofia ausente $(3 ; 5 ; 6 ; 7 ; 8 ; 9 ; 10-80 \%)$. A condição da musculatura presente no transoperatório, o tempo de evolução e lado acometido, encontram-se no apêndice D e F, quadro 4 e gráfico 1.

Os músculos suturados foram os músculos coccígeo e músculo esfíncter anal externo, o músculo coccígeo e músculo obturador interno e músculo obturador interno e esfíncter anal externo. Em média foram realizadas três a cinco pontos (PSS) em cada grupo muscular com náilon monofilamentoso 2-0, na dependência do tamanho da hérnia perineal e do porte do animal operado.

O retalho de membrana de pericárdio eqüino variou entre $2,5 \mathrm{~cm}$ até 3,5 $\mathrm{cm}$ de comprimento com 1,0 cm a 2,0 cm de largura, aproximadamente, na dependência do porte do animal. Foi suturado ao plano muscular com PSS em náilon monofilamento 30. A obtenção de fragmento apropriado ao tamanho do plano muscular suturado anteriormente foi de fácil realização, havendo, entretanto a necessidade de habilidade manual moderada para a confecção dos pontos em PSS suficientes para manter a membrana perfeitamente esticada e sem dobras (geralmente entre 13 a 15 PSS).

Após o procedimento cirúrgico proposto, a sutura em boca de tabaco e a gaze inserida no lúmen do reto foram retiradas, e realizou-se o toque retal. Não foi encontrado fio cirúrgico na luz do reto e observou-se integridade e firmeza do plano muscular perineal operado. 


\subsection{PERÍODO PÓS - OPERATÓRIO (P.O.)}

O período pós-operatório, imediato e mediato, correspondeu à recuperação do animal até a retirada dos pontos de sutura de pele, e variou de 11 a 20 dias (média de 14,6 dias) no Grupo I e de sete a 17 dias (média de 14,2 dias) no Grupo II. Em ambos os grupos observaram-se as seguintes complicações pós-operatórias:

\subsubsection{Grupo I - Período P.O. Imediato e Mediato}

Com relação ao trato digestório observou-se: hiporexia (n $3-20 \%)$, aquesia $\left(n^{\circ}\right.$ 3; $5-40 \%$ ), disquesia ( $n^{\circ} 4-20 \%$ ), tenesmo ( $n^{\circ} 1 ; 4-40 \%$ ) observados no $1^{\circ}$ e $2^{\circ}$ dia de PO $\left(n^{\circ} 1 ; 4-40 \%\right)$ e incontinência fecal $\left(n^{\circ} 1-20 \%\right)$ durante o $1^{\circ}$ e $2^{\circ}$ dia de PO até o $10^{\circ}$ dia de PO (n' $\left.1-20 \%\right)$.

No quesito pele: ferida cirúrgica da orquiectomia, eritematosa ( ${ }^{\circ} 1-20 \%$ ), ferida cirúrgica da herniorrafia, eritematosa ( $\left.{ }^{\circ} 1 ; 2 ; 5-60 \%\right)$, cujo eritema ventral se estendeu até ao $7^{\circ}$ dia $\left(n^{\circ} 1 ; 5-40 \%\right)$ e $10^{\circ}$ dia de PO (n $\left.5-20 \%\right)$, e com presença de seroma ( $\left.n^{\circ} 1 ; 4 ; 5-60 \%\right)$ do $7^{\circ}\left(n^{\circ} 1,3-40 \%\right)$ até ao $10^{\circ}$ dia de PO (no $\left.3-20 \%\right)$, edema firme ao longo do corte cirúrgico da herniorrafia $\left(n^{\circ} 2 ; 3 ; 4 ; 5-80 \%\right)$ que persistiu do $2^{\circ}$ até ao $7^{\circ}$ dia de PO $\left(n^{\circ} 3-20 \%\right)$.

Com relação ao aspecto da ferida cirúrgica, observaram-se os seguintes aspectos conforme tabela 1. 
Tabela 1 - Aspectos observados na ferida cirúrgica até o $15^{\circ}$ dia de pós-operatório (PO), segundo percentual de animais avaliados:

\begin{tabular}{lcccc}
\hline Aspecto & $2^{\circ}$ Dia P.O & $7^{\circ}$ Dia P.O & $10^{\circ}$ Dia P.O & $15^{\circ}$ dia P.O \\
\hline Eritema & $60 \%$ & $40 \%$ & $20 \%$ & $0 \%$ \\
\hline Seroma & $60 \%$ & $40 \%$ & $20 \%$ & $0 \%$ \\
\hline Edema firme & $80 \%$ & $20 \%$ & $0 \%$ & $0 \%$ \\
\hline
\end{tabular}

O Escore de evacuação observado nos animais variou de 0 (n $\left.{ }^{\circ} 2 ; 4 ; 5-60 \%\right), 1$ $\left(n^{\circ} 3-20 \%\right)$ e $3\left(n^{\circ} 1-20 \%\right)$.

O toque retal permitiu averiguar a integridade do diafragma pélvico póscirúrgico (100\%), e o aparecimento do enfraquecimento do diafragma contra-lateral após 10 dias de PO em um caso $\left(n^{\circ} 1-20 \%\right)$.

Observou-se também infecção de ferida cirúrgica (nº 1 - 20\%), ruptura e deiscência do diafragma levando à recidiva da hérnia perineal (nº $1-20 \%)$, ruptura e deiscência da pele levando à evisceração (nº 1 - 20\%).

O lado acometido pela hérnia perineal, o conteúdo herniário transoperatório e as observações do pós-operatório imediato e tardio dos pacientes do grupo I, estão discriminados no apêndice D, quadro 5.

\subsubsection{Grupo II - Período P.O. Imediato e Mediato}

Com relação ao trato digestório observou-se: disquesia observado no $1^{\circ}$ dia de PO (n $9-20 \%)$ e incontinência fecal $\left(n^{\circ} 6-20 \%\right)$ até ao $10^{\circ}$ dia de PO. 
No quesito pele: ferida cirúrgica da orquiectomia eritematosa ( $\mathrm{n}^{\circ}$ 6;8 - 40\%), ferida cirúrgica da herniorrafia eritematosa $\left(n^{\circ} 6-20 \%\right)$, cujo eritema se estendeu até ao $10^{\circ}$ dia de PO, com presença de seroma $\left(n^{\circ} 6 ; 9-40 \%\right)$ do $7^{\circ}\left(n^{\circ} 6 ; 9-40 \%\right)$ ao $10^{\circ}$ dia de PO (n 9 - 20\%), edema firme ao longo do corte cirúrgico da herniorrafia (100\%) que persistiu até ao $7^{\circ}$ dia $\left(n^{\circ} 6 ; 7 ; 9 ; 10-80 \%\right)$ e $10^{\circ}$ dia de PO $\left(n^{\circ} 9-20 \%\right)$.

Com relação ao aspecto da ferida cirúrgica, observaram-se os seguintes aspectos conforme tabela 2.

Tabela 2 - Aspectos observados da ferida cirúrgica até o $15^{\circ}$ dias de pós-operatório (PO), segundo o percentual de animais avaliados

\begin{tabular}{lcccc}
\hline Aspecto & $2^{\circ}$ Dia P.O & $7^{\circ}$ Dia P.O & $10^{\circ}$ Dia P.O & $15^{\circ}$ Dia P.O \\
\hline Eritema & $20 \%$ & $40 \%$ & $40 \%$ & $20 \%$ \\
\hline Seroma & $40 \%$ & $40 \%$ & $20 \%$ & $0 \%$ \\
\hline Edema firme & $100 \%$ & $80 \%$ & $20 \%$ & $20 \%$ \\
\hline
\end{tabular}

Observou-se também contaminação de ferida cirúrgica por lambedura local da orquiectomia ( ${ }^{\circ} 8$ - 20\%), ruptura e deiscência da sutura de pele levando exposição do tecido subcutâneo ( $n^{\circ} 7$ - 20\%) e incontinência urinária (nº 6;9 - 40\%) que permaneceu por até 10 dias (n 9 - 20\%) e 17 dias de PO (nº 6 - 20\%).

O Escore de evacuação variou de 0 (nº 6;7;8;10 - 80\%) a 1 (n 9 - 20\%).

O toque retal permitiu averiguar a integridade do diafragma pélvico póscirúrgico (100\%). Um dos pacientes $\left(n^{\circ}\right.$ 9) foi encaminhado ao Serviço de Cardiologia do Departamento de Clinica Médica HOVET/FMVZ/USP, devido à piora da tosse, cansaço fácil mais acentuada e a ocorrência de síncope, cursando para óbito. 
Estão discriminados no apêndice E, quadro 6: o lado acometido, o conteúdo trásoperatório e complicações pós-operatórias imediatas e tardias dos pacientes do grupo II.

No período pós-operatório tardio - com 30, 60 e 90 dias de acompanhamento foi possível verificar que os pacientes encontravam-se em bom estado geral, alimentando-se ainda com ração em lata $\left(n^{\circ} 1-10 \%\right)$, dieta caseira acrescida de fibra $\left(n^{\circ} 2 ; 3 ; 6 ; 7 ; 8 ; 9\right.$ - 60\%), dieta caseira acrescida de fibra e ração (nº 4;5;10 30\%).

O paciente (n $\left.{ }^{\circ} 9-10 \%\right)$ que foi encaminhado ao Serviço de Cardiologia iniciou quadros de síncopes freqüentes e aumento dos episódios de tosse, devido à piora do quadro de Insuficiência Cardíaca da Válvula Mitral (IVMC). Evoluiu para edema pulmonar e insuficiência renal aguda (U: $235 \mathrm{mg} / \mathrm{dl}$ e C: 2,0 mg/dl) vindo a óbito no final de semana durante fluidoterapia realizado por colega em clínica particular, aos 20 dias de pós-operatório, não sendo possível portanto a avaliação ultra-sonografia e radiográfica do pós- operatório tardio. Ao exame pós - morten o diafragma pélvico operado (Direito) encontrava-se íntegro e houve incorporação da membrana biológica pericárdio de eqüino à parede da musculatura (Apêndice K, Figuras 23 a 28).

O exame clínico nos retornos dos pacientes ao Serviço de Cirurgia de Pequenos Animais, possibilitou verificar que houve ganho de peso corporal gradativo em todos os pacientes.(em média 15,1\% de ganho de peso).

\subsubsection{Grupo I - Período P.O. Tardio}

- Esporadicamente exposição da mucosa anal quando no ato de defecar ( $n^{0} 1$ - 20\%). 
- Integridade do diafragma pélvico operado persistente por até 90 dias de PO (nº 2;4;5 $60 \%)$.

- Recidiva da hérnia perineal no pós-operatório imediato (nº 1 - 20\%).

- Recidiva da hérnia perineal aos 60 dias de PO (n 3 - 20\%).

- Fragilidade do diafragma pélvico contra lateral observado aos 30 (nº 5 - 20\%) e 60 dias de PO $\left(n^{0} 1 ; 5-40 \%\right)$.

- Diminuição do aumento do lume retal - quando presente (nº 4 - 20\%).

- Necessidade de segunda intervenção cirúrgica na região perineal afetada $\left(\mathrm{n}^{0} 1 ; 3\right.$ $40 \%)$

\subsubsection{Grupo II - Período PO Tardio}

- Integridade do diafragma pélvico operado persiste por até 90 dias de PO (100\%)

- Diminuição do aumento do lume retal - quando presente (nº 7 - 20\%)

4.9 AVALIAÇÃO DOS EXAMES TARDIOS PÓS-OPERATÓRIOS DE IMAGEM ULTRA - SONOGRÁFICOS

O exame ultra-sonográfico realizado pelo Serviço de Diagnóstico por Imagem do HOVET/USP, no pós-operatório tardio, seguiu-se conforme estabelecido no período pré-operatório. 
Examinando-se o trato gênito-urinário, pode-se constatar: rins com contornos preservados ( $\mathrm{n}^{\mathrm{o}}$ 1;2;3;5;6;7;8;10 - 88\%), limite córtico medular definido $\left(\mathrm{n}^{\mathrm{o}}\right.$ 1;2;3;5;6;7;8;10 - 88\%), com a ecogenicidade mantida ( $n^{\circ} 1 ; 2 ; 3 ; 5 ; 6 ; 7 ; 8 ; 10$ - 88\%). Dentre as alterações renais observadas, pôde-se descrever: rins de tamanho reduzido ( $\mathrm{n}^{\circ}$ 4 - 11\%), limite córtico - medular pouco definido (n 4 -11\%), ecogenicidade discretamente elevada ( $n^{0} 5-11 \%$ ), pelve renal discretamente dilatada ( $n^{\circ} 4-11 \%$ ) e cisto anecóico em cortical renal ( $\left.{ }^{0} 4-11 \%\right)$.

A vesícula urinária encontrava-se em sua posição anatômica normal $\left(n^{\circ}\right.$ 2;4;5;6;7;8;10 - 77\%) ou deslocada caudalmente $\left(n^{\circ} 1 ; 3\right.$ - 22\%). As alterações observadas ao exame foram: espessamento e irregularidades de parede da vesícula urinária (nº 3;4;7 - 33\%), presença de estruturas hiperecóicas produtoras de sombra acústica no seu interior - cálculos (nº 4;10 - 22\%).

Diminuição do volume prostático $\left(\mathrm{n}^{\circ}\right.$ 2;3;4;5;6;7;8;10 - 88\%). A próstata não pode ser visualizada devido à localização intra-pélvica (nº 1 - 11\%)

A próstata pôde ser bem avaliada exceto em um animal, pois a próstata, encontrava-se na região intra-pélvica, e não foi possível o exame adequado, por meio de ultra-som. Nos demais paciente foi possível observar: localização anatômica normal ( $\mathrm{n}^{\circ}$ 2;4;5;6;7;8;10 - 77\%), localização anatômica ectópica (nº 3 - 11\%); diminuição do tamanho e volume prostático $\left(n^{\circ} 2 ; 3 ; 4 ; 5 ; 6 ; 7 ; 8 ; 10\right.$ - 88\%), parênquima homogêneo $\left(n^{\circ}\right.$ 2;3;4;5;6;7;8;10 - 88\%). O diâmetro da próstata no final de 90 dias variou de 1,8 cm a 2,7 cm de diâmetro, em média 1,79 cm de diâmetro. Foi observado dilatação da uretra prostática em um dos pacientes $\left(\mathrm{n}^{0} 2-11 \%\right)$.

Dentre os achados ultra-sonográficos, descritos anteriormente, manteve-se a esplenomegalia em um caso ( $\left.n^{\circ} 8-11 \%\right)$. Os novos achados durante o exame foram: fígado com dimensões reduzidas $\left(n^{0} 7-11 \%\right)$ com ecogenicidade discretamente elevada 
$\left(n^{0} 7-11 \%\right)$ e com presença de estrutura irregular hiperecóica produtora de sombra acústica em vesícula biliar - cálculo (nº 7 - 11\%).

\subsection{AVALIAÇÃO DOS EXAMES TARDIOS PÓS-OPERATÓRIOS DE IMAGEM RADIOGRÁFICOS}

O exame radiográfico pós-operatório tardio transcorreu conforme o préoperatório.

Ao exame radiográfico simples foi possível detectar conteúdo fecal $\left(\mathrm{n}^{\circ}\right.$ 1;2;3;5;10 - 55\%) e gasoso em cólon e reto $\left(n^{\circ}\right.$ 6;7 - 22\%). Vesícula urinária em região hipogástrica, deslocada caudalmente ( $n^{\circ}$ 5;6;10 - 33\%), obesidade ( $n^{\circ} 5-11 \%$ ). Região perineal sem alterações dignas de nota (100\%).

O exame radiográfico contrastado - uretrocistografia - permitiu melhor visualização da vesícula urinária e uretra prostática, constatando: deslocamento caudal da vesícula urinária para região hipogástrica (nº $1 ; 2 ; 3 ; 5 ; 7 ; 10$-66\%); espessamento $\left(\mathrm{n}^{\mathrm{0}} 2 ; 4 ; 7 ; 8-44 \%\right)$ e irregularidade da superfície de mucosa da parede vesical $\left(\mathrm{n}^{\mathrm{o}}\right.$ 1;4;7;8;10 - 55\%); deslocamento da uretra prostática em canal pélvico e também para a região perineal ( $\left.n^{\circ} 3 ; 7-22 \%\right)$; uretra prostática discretamente dilatada ( $\left.n^{\circ} 10-11 \%\right)$; silhueta prostática não observada por estar em região intra-pélvica $\left(n^{0} 1 ; 2 ; 3 ; 5 ; 7 ; 8 ; 10\right.$ $-77 \%)$. 
Os exames ultra-sonográficos e radiográficos realizados no Serviço de Diagnóstico por Imagem do Departamento de Cirurgia da FMVZ/ USP junto ao HOVET/USP, no período pós operatório tardio permitiram verificar:

\subsubsection{Grupo I}

- região perineal sem alterações dignas de nota.(nº 1; 2; 3; 5 - 80\%);

- espessamento e irregularidade de mucosa em pólo cranial de vesícula urinária, sugestivo de cistite crônica ( $n^{0}$ 1;4 - 40\% e $n^{\circ} 1 ; 2 ; 3-60 \%$, respectivamente);

- deslocamento da bexiga para região hipogástrica $\left(\mathrm{n}^{0} 1 ; 2 ; 3-60 \%\right)$;

- localização anatômica da próstata $\left(n^{0} 1 ; 2 ; 3 ; 5\right.$ - 80\%);

- localização ectópica da próstata em períneo (n 3 - 20\%);

- uretra prostática em canal pélvico com deslocamento para região perineal (nº 3 - 20\%)

- dilatação da uretra prostática (nº 2 - 20\%);

- posicionamento anatômico de cólon e reto $\left(\mathrm{n}^{0}\right.$ 1; 2; 3; 4; 5 - 100\%).

\subsubsection{Grupo II}

- região perineal sem alterações dignas de nota $\left(n^{\circ} 6 ; 7 ; 8 ; 10-100 \%\right)$;

- deslocamento caudal da vesícula urinária para região hipogástrica (nº 6; 7; 10 - 75\%); 
- espessamento e irregularidade de superfície de mucosa da vesícula urinária $\left(n^{0} 7 ; 8\right.$ $50 \%$ e ${ }^{\circ} 7 ; 8 ; 10-75 \%$, respectivamente);

- posicionamento anatômico da próstata para canal intra-pélvico (nº 7; 8; 10 - 75\%);

- próstata extra-pélvica em região hipogástrica (nº 6 - 25\%);

- uretra prostática dilatada (nº 10 - 20\%);

- posicionamento anatômico de cólon e reto (nº 6; 7; 8;10 - 100\%). 
V - DISCUSSÃO 
Os resultados obtidos neste trabalho frente à perquirição bibliográfica permitem tecer comentários, com a finalidade de discussão do tema, conforme exposto a seguir.

A idade média dos pacientes situou-se em 10,3 anos, próximo do encontrado por estudos realizados com 76 e 100 cães, que descreveram nove e 10 anos respectivamente, como a idade média de observação de hérnia perineal (HOSGOOD et al., 1995; ORSHER et al., 1986). Matera et al. (1981) e Frankland et al. (1986) realizaram estudos com grupos menores e observaram, respectivamente, a idade média de oito anos e nove anos, dados próximos, porém inferiores à média observada por nós.

Ainda que a maioria dos cães neste estudo seja de porte pequeno a médio - peso corporal 8,3 kg - Hosgood et al. (1995), diferentemente, relataram a referida doença em animais de porte médio a grande com peso corporal médio de 13,9 kg.

Pelo menos $50 \%$ dos animais deste trabalho, foram encaminhados ao HOVET/FMVZ/USP para tratamento de hérnia perineal, enviado por médico veterinário que as examinaram em clínica particular. Neste caso, a maioria já estava sendo medicada com medicamentos ou procedimentos (esvaziamento manual do reto) que evitassem o acúmulo de fezes na ampola retal (BELLENGER et al. 1998). Tais procedimentos foram avaliados por Harvey et al. (1997) como alternativo à cirurgia e embora fosse benéfico onde o esforço para evacuação era infreqüente, assim como observado neste estudo, não foi obtido sucesso no controle permanente dos sinais clínicos que acompanham a formação herniária. Portanto, entende-se que somente a herniorrafia pode eficazmente, ressalvadas as complicações, resolver o quadro clínico de hérnia perineal do cão. 
Conforme o observado, os proprietários demoraram em média quatro meses para procurar local que promovesse a correção cirúrgica da paratopia, provavelmente porque muitos não perceberam o aumento de volume lateral ao ânus, ou não deram a devida importância à disquesia que o animal vinha apresentando, conforme já relatado na literatura. Assim, Orsher et al. (1986) relatam que em média transcorreram 7,4 meses desde o aparecimento dos sintomas até a correção cirúrgica da hérnia perineal dos animais do seu estudo, período relativamente maior quando comparado com o nosso observado (quatro meses em média).

Os principais sintomas observados nos animais pertencentes ao presente estudo foram: o aumento de volume lateral ao ânus (100\%), predominantemente do lado direito (60\%), disquesia em 90\%, tenesmo em $40 \%$, hiporexia em $30 \%$ e emese ocasional em 30\% dos pacientes. Diante destes dados observa-se que são semelhantes aos descritos pela literatura (HEDLUND, 2002; HOSGOOD et al., 1995). O acometimento, sobretudo do lado direito também foi observado por Weaver et al. (1981); Desai et al. (1982) e Daleck (1992). Em trabalho de Burrows et al. (1975), ocorreu diarréia, pelo menos ocasionalmente, em mais de $50 \%$ dos casos. Contudo no presente estudo, o aspecto das fezes demonstrou ser, sobretudo de consistência pastosa, em formato de fita (60\%) e quando presente o tenesmo e grande esforço no ato de evacuação, estrias de sangue puderam ser vistas misturado ao bolo fecal.

Ao se questionar o proprietário sobre como ocorria a defecação antes do tratamento proposto, 10\% declarou apenas que ocorria com dificuldade (escore de evacuação 1), 50\% com dificuldade e esforço (escore de evacuação 2) e 30\% com dificuldade, esforço e dor (escore de evacuação 3). O escore de evacuação permitiu ajustar a dosagem de medicamentos laxativos e dieta, permitindo conforto ao animal e providenciando maior tranqüilidade ao proprietário. Possibilitou também, obter através 
do proprietário, informações que auxiliassem no diagnóstico de disquesia e tenesmo, embora, tais informações venham do poder de observação do proprietário, tratando-se, portanto, de resultado subjetivo e impreciso. Não foi citado na literatura tal tipo de gradação. Ao utilizar-se o escore de evacuação, a disquesia foi relatada em $90 \%$ dos casos, com tendência ao tenesmo, ao menos ocasional em 30\%, semelhante ao observado em estudo com 100 cães realizado por Hosgood et al. (1995), que descreveram tenesmo em 30\% e impossibilidade de evacuação em 23\%.

Assim como descrito por Hedlund (2002), nenhum dos animais apresentou prolapso de reto devido à severa disquesia. Provavelmente porque, de modo intuitivo, os proprietários já empregavam alimentos mais umedecidos ou oleosos para controle da defecação em seus animais, mesmo antes de buscarem socorro médico veterinário.

Hosgood et al. (1995) em sua pesquisa comentam que ao realizar o toque retal, percebeu alteração na região perineal em 31\%, impactação fecal em 10\%, prostatomegalia em $10 \%$ e bexiga retrofletida observada por exame radiográfico em 20\%. Nos animais que apresentaram bexiga retrofletida, os níveis séricos de uréia e creatinina estavam elevados significativamente e leucocitose neutrofílica era percebida pelo hemograma (HOSGOOD et al., 1995). Por este trabalho realizado em 10 animais, ao toque retal percebeu-se perda da integridade do diafragma pélvico em $100 \%$, desvio de reto em 60\%, aumento do lume retal em $40 \%$ e próstata aumentada e com sensibilidade dolorosa em 30\%, impactação fecal severa, na qual houve necessidade de esvaziamento retal manual em $10 \%$.

Através dos exames de imagem, foi possível identificar a bexiga retrofletida por exame radiográfico em $22 \%$ dos pacientes, semelhante ao encontrado por Hosgood et al. (1985), mas estes autores não citam o deslocamento da vesícula urinária para canal pélvico, que neste presente estudo foi encontrado em 55\% dos animais radiografados. 
Através do exame ultra - sonográfico 30\% dos pacientes tinham bexiga deslocada para canal pélvico, $10 \%$ apenas uma pequena parte localizada no aumento de volume perineal e 30\% como conteúdo da hérnia perineal. Acredita-se que a discrepância entre os conteúdos (bexiga) deve-se á mobilidade dos órgãos presentes no conteúdo herniado. Os níveis séricos de uréia e creatinina encontravam-se normais, mesmo entre aqueles que apresentavam vesícula urinária fazendo parte do saco herniário, mas pelo hemograma segue-se leucocitose neutrofílica conforme descrita por Hosgood et al. (1985).

Alguns autores como Rochat e Mann (1998) e Sjollema (1989), imputam a atrofia ou ruptura do músculo elevador do ânus como uma das grandes causas da ocorrência das hérnias perineais. Sjollema (1993) chega a afirmar que muitas vezes, a porção caudal do músculo elevador do ânus, não é observada devido à intensa atrofia. Neste presente trabalho, perceberam-se graus variados de atrofia nos músculos da região operada, também mais evidente no músculo elevador do ânus, seguido dos músculos esfíncter anal externo e coccígeo. Em 50\% dos animais operados, o músculo elevador do ânus, encontrava-se em tão severa atrofia, que não foi possível distingui-lo. A causa que leva a severa atrofia, não é de todo compreendida, mas dentre estes animais, $40 \%$ tinham a hérnia do lado direito e o tempo de evolução médio de 4,8 meses. O músculo obturador interno, usado para auxiliar o fechamento do defeito, foi o que se mostrou menos afetado, porém também se verificou atrofia discreta em pelo menos 30\% dos pacientes. Os dois casos de recidiva ocorreram quando houve perda da sustentação do diafragma pélvico promovido pela heniorrafia. Em ambos, o músculo elevador do ânus era ausente. Em um deles a atrofia do esfíncter anal externo era severa em associação com atrofia moderada do músculo obturador. No outro paciente, os músculos esfíncter anal externo e coccígeo encontravam-se em atrofia discreta e moderada 
respectivamente. Nestes casos, dois importantes músculos de sustentação, o obturador e o coccígeo estavam mais afetados. A utilização do retalho de pericárdio de eqüino conservado em glicerina a 98\%, teriam sido benéficos para promover melhor apóio na sutura muscular realizada em ambos os pacientes, o que vem corroborar com os efeitos positivos adjutórios da membrana à técnica de correção de hérnia perineal pela elevação do músculo obturador interno.

Durante a cirurgia, ao acessar o conteúdo herniário, identificou-se gordura retroperineal (80\%), epíplon (40\%), próstata (50\%), bexiga retrofletida (30\%), aumento do lume retal (10\%), cistos, aderências e fibrose (10\%). Dos 100 animais pesquisados por Hosgood (1985), em 32\% foram descritos o conteúdo herniado: gordura retroperineal em $43,75 \%$, próstata $12,50 \%$, bexiga $62,50 \%$ e intestino delgado em 6,25\%. Hosgood et al. (1985) não exemplificam o caso em que foram encontradas as alças intestinais jejunais, mas deve ter sido em animal cuja amplitude do defeito da parede muscular do períneo seja significativa, permitindo a entrada de muitos órgãos, não só intestino grosso no saco herniário, associada à provavelmente à intensa disquesia ou tenesmo. Defeito de amplitude muito grande não foi identificado nos pacientes deste estudo e ao utilizarem-se laxantes e dieta rica em fibra e umidade, conseguiu-se abrandar o desconforto e esforço do animal ao defecar.

A realização da orquiectomia e da herniorrafia utilizando-se retalho de membrana foi proposta ao proprietário e aceita sem dificuldades. O procedimento proposto ao estudo foi realizado sem complicações durante o transoperatório e exigiu apenas habilidade manual para a confecção do retalho de pericárdio eqüino em formato “de pêra” (triângulo com a base levemente arredondada) e a fixação no local. O material foi fixado à herniorrafia realizada com fio monofilamento de náilon 3-0 em pontos simples separados de modo que a membrana ficasse perfeitamente esticada e adaptada à 
linha de sutura muscular previamente realizada, e para isso obteve-se um acréscimo em média de 18 minutos, no tempo geral de cirurgia. Daleck (1986) e Matera (1981) utilizaram peritônio de bovino conservado em glicerina e malha de polipropileno respectivamente, suturado nas bordas do defeito perineal. As suturas foram realizadas com material absorvível em pontos simples separado e em contínuo por Daleck (1986) e em pontos separados simples por Matera (1981). O formato oval e tamanho variável com as dimensões do orifício herniário foi utilizado por Matera (1981) para ocluir o defeito perineal. Tal procedimento foi realizado neste mesmo estudo, ao adaptar-se a membrana cortada em formato oval (pêra) aos diferentes tamanhos de abertura pélvica, porém em repouso sobre a herniorrafia realizada momentos antes. Ambos os pesquisadores não comentam o acréscimo de tempo necessário para realizar tais procedimentos, mas no presente trabalho, o acréscimo ao tempo médio de cirurgia (dezoito minutos), correspondeu ao empregado para a sutura do fragmento da membrana biológica de pericárdio de eqüino à musculatura perineal já previamente suturada.

A herniorrafia perineal tem sido associada com altos índices de complicações pós-operatórias que incluem: recidiva (10 a 46\%), fístula e abscessos, prolapso retal, incontinência urinária ou fecal e injúria do nervo ciático (HOSGOOD et al., 1985). Estes índices variam conforme o método empregado para a reparação do defeito perineal. Com relação à herniorrafia por transposição ou elevação do músculo obturador interno encontra-se no pós-operatório imediato: 4,6 \% de recidiva, infecção 12\%. No pós-operatório tardio: recidiva 3\% e fístulas 12\% (SJOLLEMA et al., 1989). Com efeito, nos animais do grupo I - que foram submetidos à herniorrafia por transposição ou elevação do músculo obturador interno - observaram-se no pós-operatório imediato: recidiva 20\%, evisceração 20\%, infecção local 20\% e incontinência fecal 20\%. Outros 
sintomas como hiporexia $20 \%$ e alterações de trânsito intestinal como aquesia $40 \%$, disquesia $20 \%$ e tenesmo $40 \%$ foram observados e também relatados na literatura. Robertson (1983) já observava que esforço e dificuldade podem ocorrer no pósoperatório imediato e que pode associar-se com prolapso retal em alguns casos. Matthiesen (1989) relaciona o tenesmo pós-operatório e as infecções, abscessos e fístulas retocutâneas com a penetração de sutura para o interior da mucosa do reto, porém em nenhum animal operado foi encontrada sutura penetrante, ao menos por palpação retal em seguida ao procedimento e durante o período subseqüente. Dieterich (1975) indica a utilização de supositório de glicerina naqueles animais que não apresentam trânsito intestinal depois de 48 horas de pós-operatório. Hedlund (2002) indica que a administração de laxantes formadores de massa fecal macia seja mantida por período de 1 a 2 meses após a herniorrafia. Não houve a necessidade de empregar supositórios de glicerina, mas a utilização de laxantes foi mantida por período mínimo de 20 dias após a intervenção cirúrgica, visto que ocorreram casos de disquesia e tenesmo. Tal medida foi importante para se evitar o esforço com conseqüente reflexo sobre a musculatura recentemente suturada. As fezes, entretanto quando muito líquidas, dificultavam a limpeza da região. O escore de evacuação variou de 0 (60\%), 1 (20\%) e 3 (20\%). A retirada dos pontos foi possível em média 14 dias. Tal período é semelhante ao recomendado por Dieterich (1975) entre 10 e 14 dias.

Vale ressaltar que o animal que apresentou ruptura da sutura da herniorrafia perineal apresentou tenesmo intenso após a realização do toque retal para averiguar a integridade do diafragma. Motivo pelo qual, o toque retal só foi realizado nos demais animais após um período mínimo de cinco dias. A evisceração observada após quatro dias, deveu-se à contaminação da ferida e a retirada da sutura de sustentação da pele devida á lambedura constante do animal à ferida cirúrgica, pois o mesmo não utilizava 
colar protetor conforme solicitado. A indicação de uso do colar Elizabetano já fora recomendada por Dieterich (1975) e Robertson (1983). Com aspecto ao cuidado da ferida cirúrgica, a limpeza e o impedimento da lambedura no local, são de suma importância, para a obtenção de perfeita cicatrização e diminuição das muito já prováveis complicações. Muitas vezes o uso de tal procedimento demonstrou ser de difícil adaptação por parte do proprietário e não do cão.

No pós-operatório tardio foram presenciados: esporadicamente exposição da mucosa anal quando no ato de defecar 20\%, recidiva aos 60 dias de pós - operatório $20 \%$, diminuição do aumento do lume retal - quando presente $20 \%$, necessidade de segunda intervenção cirúrgica na região perineal afetada 40\%. Robertson (1983) relaciona o prolapso de reto com conseqüência de esforço ao defecar, observado nos primeiros dias de pós-operatório. Neste caso, a mucosa anal não chegava a se protuir completamente, ocorria apenas ocasionalmente, e deve-se a perda de parte da contratilidade do esfíncter anal.

Orsher et al. (1984) descreveram a técnica por transposição ou elevação do músculo obturador interno e perceberam como complicações: infecção (6,45\%), seroma (6,45\%), prolapso retal (12,90), incontinência urinária (6,45\%), flatulência (35,48\%), próstata localizada intrapélvica (64,51\%) e intra - abdominal (32,25\%). Não foi relatada, por parte do proprietário a ocorrência de flatulência após a herniorrafia proposta. A incontinência urinária também não foi observada nos animais do grupo I, no pós-operatório tardio. A presença de seroma, eritema e edema firme discreto (calor, rubor, tumor) foram encontrados em quase todos os animais no período pós-operatório, no entanto, não ocasionando maiores problemas. Provavelmente, se os cães permanecessem em internação, com administração correta de antibióticos, higienização da ferida feita de forma correta e a utilização de colar protetor conforme indicado, o 
índice de infecção deste presente estudo seria equivalente ao encontrado por Orsher (1984) e Sjollema et al. (1989).

Nos animais do grupo II - que foram submetidos ao mesmo procedimento, porém com colocação de retalho de pericárdio de eqüino, observaram-se no pósoperatório imediato: disquesia 20\%, incontinência fecal 20\%, ruptura e deiscência da sutura de pele levando exposição do tecido subcutâneo (20\%), contaminação de ferida cirúrgica tardia por lambedura local da orquiectomia (20\%) e incontinência urinária (40\%) que permaneceu por até 17dias (20\%). O Escore de evacuação variou de 0 (80\%) a 1 (20\%). A retirada dos pontos foi possível em média 16 dias. Como o processo inflamatório demonstrou ser mais expressivo quando se utiliza a membrana de pericárdio eqüino, o período para a retirada de sutura se estendeu em pelo menos 2 dias em média. Embora Matera (1981) e Daleck (1986) tenham retirado os pontos em média com 7 dias.

O animal que apresentou ruptura e deiscência da linha de sutura da pele brigou com contactante canino no dia seguinte à retirada dos pontos. (com 7 dias)

Frankland et al. (1986) empregaram colágeno dermal suíno para reparo do defeito perineal. Este material é muito utilizado em medicina humana nas hérnias abdominais. O material foi posto em contato direto com o defeito, suturando a "malha" nas bordas. Relata não ter observado complicações em 66\% dos animais, 33\% com seroma e secreção que se iniciaram do $3^{\circ}$ ao $4^{\circ}$ dia de pós-operatório e que se estenderam por até 8 dias deiscência de sutura de pele em 5\% e 10\% de recidiva após 2 anos de observação. O autor considera um sucesso moderado. Neste presente estudo, no grupo II - onde foi utilizado o pericárdio eqüino - o processo inflamatório se estendeu em todos os pacientes (100\%), com produção de edema firme no local, eritema e seroma que se estenderam do $3^{\circ}$ ao $10^{\circ}$ dia de pós - operatório em $100 \%$ dos animais, e 
permaneceram por até o $15^{\circ}$ dia em $40 \%$ deles. Recidivas não foram observadas por até 90 dias de pós-operatório, mas o material foi empregado como reforço de herniorrafia, diferentemente de Frankland (1986) que utilizou o material ancorado nas bordas da musculatura para correção do defeito do diafragma perineal.

Daleck (1986) realizou trabalho semelhante à Frankland (1986), mas utilizou peritônio de bovino conservado em glicerina para o reparo da hérnia perineal e considera o material empregado como excelente para a reparação inclusive de diversos órgãos. A sutura da membrana foi realizada na borda da musculatura com 4 pontos de apoio e em seguida com sutura contínua, utilizando-se fio absorvível categute cromado $n^{0}$. 1. Apresentou deiscência de sutura de pele e evisceração em 15,38\% (2/13) no pósoperatório imediato e recidiva após 3 meses de pós-operatório em 7,69\% (1/13). Fístula perineal não foi observada. Daleck (1986) relata que a deiscência de sutura com conseqüente evisceração deve-se à contaminação da ferida cirúrgica no momento da cirurgia o que neste trabalho realizado não foi observado no grupo II, provavelmente pela utilização de antibióticos de amplo espectro por via sistêmica no transoperatório e no momento da colocação do pericárdio eqüino na musculatura reconstituída. Raiser (1994) relata que o fio categute não oferece sustentação por suficiente para a cicatrização. Afirma que segundo Bellenger (1980) e Bojrab (1986) uma resposta inflamatória prolongada determina maior grau de fibrose e, portanto, maior resistência. Nos cães aqui analisados, foram utilizados materiais de sutura não absorvíveis monofilamentoso (náilon) e o que determinou prolongamento da resposta inflamatória foi a membrana pericárdio de eqüino conservado em glicerina a 98\%. Esta característica propicia maior reforço no local de sutura.

Neste presente trabalho, durante o pós-operatório tardio observou-se: integridade do diafragma pélvico operado persiste por até 90 dias de PO (100\%) e diminuição do 
aumento do lume retal - quando presente (20\%). Não foram observadas fístulas ou outros indícios de contaminação na região perineal.

Comparando-se os dois grupos, percebe-se que o processo inflamatório iniciouse após o $2^{\circ}$ dia, porém manteve-se por mais tempo, com eritema, seroma e principalmente edema firme por até 15 dias de pós-operatório, naqueles pacientes que receberam o retalho de membrana pericárdio eqüino. Porém este grupo não apresentou ruptura da musculatura do diafragma perineal operada. Para o proprietário, exigiu-se maior atenção e cuidado, pois a inflamação local mostrou-se maior.

Em ambos os grupos, aos exames radiográficos e ultra-sonográficos, destacamse o deslocamento de vesícula urinária para canal pélvico (20\% e 25\%, grupos I e II respectivamente), diminuição do volume prostático (88\%), posicionamento anatômico da próstata para canal intra-pélvico (grupo I - 80\% e grupo II - 75\%), deslocada caudalmente (20\% grupo I) e intra-abdominal (25\% grupo II), dilatação da uretra prostática (grupo I - 20\% e grupo II - 25\%) e posicionamento anatômico de cólon e reto (100\%). Conseqüências já observadas e relatadas por outros autores como Orsher (1984); Hosgood (1985) e SJOLLEMA (1989) e que são provenientes da herniorrafia por transposição ou elevação do músculo obturador interno. O reforço no diafragma pélvico proveniente pelo acréscimo de membrana de pericárdio de eqüino na herniorrafia permitiu o posicionamento da próstata em posição anatômica ou em região hipogástrica (100\%). No grupo que não recebeu membrana de pericárdio eqüino, a próstata também se apresentou deslocada caudalmente para o canal pélvico devido à falta de sustentação realizada pela herniorrafia em um dos animais. ( $\left.\mathrm{n}^{0} 3\right)$, visualizado pelo exame ultra-sonográfico e radiográfico no período pós-operatório. 
VI - CONCLUSÃO 
Diante dos resultados obtidos com a metodologia empregada é lícito afirmar-se que:

1) O implante de membrana de pericárdio de eqüino conservado em glicerina a 98\% aplicada no sítio da herniorrafia perineal por elevação do músculo obturador interno permitiu reforço do diafragma pélvico, diminuindo as possibilidades de deiscência ou ruptura deste.

2) A utilização da membrana pericárdio de eqüino conservado em glicerina a 98\%, necessitou de pequeno acréscimo ao tempo de intervenção cirúrgica de correção de hérnia perineal no cão.

3) A membrana de pericárdio de eqüino conservado em glicerina a 98\% deve ser indicada para aqueles pacientes com atrofia muscular do diafragma pélvico como reforço adicional à sutura do mesmo. 
VII - REFERÊNCIAS 


\section{REFERÊNCIAS}

ACAUI, A. Avaliação do tratamento da hérnia perineal bilateral no cão por acesso dorsal ao ânus em tempo cirúrgico único. 2001. 53 f. Tese (mestrado em cirurgia) Faculdade de Medicina Veterinária e Zootecnia, Universidade de São Paulo, São Paulo, 2001.

ANDERSON, G. I.; MCKEOWN, D. B.; PARTLOW, G. D.; PERCY, D. H. Retal resection in the dog a new surgical approach and the evaluation of its effect on fecal continence. Veterinary Surgery, v. 22, n. 2, p. 119-125, 1987.

BELLENGER, C. R. Perineal hernia in dogs. Australian Veterinary Journal, v. 56, n. 9, p. 434-438, 1980.

BELLENGER, C. R.; CANFIELD, R. B. Hernia Perineal. In: SLATTER, D. Manual de cirurgia de pequenos animais. São Paulo: Manole, 1998. p. 578-589.

BOJRAB, M. J.; TOOMEY, A. A. Hernia perineal In: BOJRAB, M. J. Cirurgia dos pequenos Animais. São Paulo: Roca, 1986. p. 436-441.

BURROWS, C. F.; HARVEY, C. E. Perineal hernia in the dog. Journal Small Animal Practice, v. 14, p. 315, 1973.

DALECK, C. R.; DALECK, C. L. M.; FILHO, J. G. P.; NETO, J. M. C. Reparação da hérnia perineal em cães com peritônio de bovino conservado em glicerina. Ciência Rural, v. 22, n. 2, p. 179-183, 1992.

DESAI, R. An anatomical study of the canine male and female pelvic diaphragm and effect of testosterone on the status of levator ani of male dogs. Journal of American Animal Hospital Association, v. 18, p. 195-202, 1982.

DIETERICH, H. F. Perineal hernia repair in canine. Veterinary Clinics of North America, v. 5, n. 3, p. 383-399, 1975.

DORN, A. S.; CARTEE, R. E.; RICHARDSON, D. C. A preliminary comparison of perineal hernia in the dog and man. Journal of the American Animal Hospital Association, v. 18, p. 624-632, 1982. 
FRANKLAND, A. L. Use of porcine dermal collagen in the repair of perineal hernia in dogs - a preliminary report. Veterinary Record, v. 119, p. 13-14, 1986.

HEDLUND, C. Perineal hernia. In: FOSSUM, T. W. Cirurgia de pequenos animais. São Paulo: Roca, 2002. p. 389-394.

HOSGOOD, G.; HEDLUND, C. S.; PEACHMAN, R. D.; DEAN, P. W. Perineal herniorrhaphy: perioperative data from 100 dogs. Journal of the American Animal Hospital Association, v. 31, n. 4, p. 331-342, 1995.

MANN, F. A.; BOOTHE, H. W.; NONNEMAN, D. J.; POPE, E. R.; WELSHONS, W. V.; GANJAM, V. K. Androgen receptors in the pelvic diaphragm muscles of dogs with and without perineal hernia. American Journal Veterinary Research, v. 56, n. 1, p. 134-139, 1995.

MANN, F. A.; BOOTHE, H. W.; AMOSS, M. S.; TANGNER, C. H.; PUGLISI, T. A.; HOBSON, H. P. Serum testosterone and estradiol 17-beta concentrations in 15 dogs with perineal hernia. Journal American Veterinary Medical Association, v. 94, n. 11, p. 1578-1580, 1989.

MANN, F. A.; ROCHAT, M. C. Sciatic perineal hernia in two dogs. Journal of Small Animal Practice, v. 39, p. 240-243, 1998.

MATERA, A.; BARROS, P. S. M.; STOPIGLIA, A. J.; RANDI, R. E. Hernia perineal no cão- tratamento cirúrgico mediante utilização de malha de polipropileno. Revista da Faculdade de Medicina Veterinária e Zootecnia da Universidade de São Paulo, v. 18, n. 1, p. 37-41, 1981.

ORSHER, R. Clinical and surgical parameters in dogs with perineal hernia analysis of result of internal obturator transposition. Veterinary Surgery, v. 15, n. 3, p. 253-258, 1986.

RAISER, A. G. Herniorrafia perineal em cães - análise de 35 casos. Brazilian Journal Veterinary Reserach Animal Science, v.31, n.3/4, p.252-260, 1994.

ROBERTSON, J. J. Perineal hernia repair in dogs. Modern Veterinary Practice, v. 65, n. 5, p. 365-368, 1984.

SJOLLEMA, B. E.; HAAGEN A. J. V.; VAN SLUIJS, F. J.; HARTMAN, F.; GOEDEGEBUURE, S. A. Eletromyography of the pelvis diaphragm and anal sphincter in dogs with perineal hernia. American Journal of Veterinary Research, v. 54, n. 1, p. 185-190, 1993.

STOPIGLIA, A. J.; ALVARENGA, J.; MORAES BARROS, P. S.; GUERRA, J. L.; IWASAKI, M. Reparation chirurgicale de la paroi thoracique du chien. Le Point Vétérinaire, v. 18, n. 97, p. 239-243, 1986 
WEAVER, A. D.; OMAMEGBE, J. O. Surgical treatment of perineal hernia in the dog. Journal of Small Animal Practice, v. 22, p. 749-758, 1981.

VAN SLUIJS, F. J., SJOLLEMA, B. E. Perineal hernia repair in the dog by transposition of the internal obturator muscle - I surgycal technique. The Veterinary Quarterly, v. 11, n. 1, p. 12-17, 1989a.

VAN SLUIJS, F.J., SJOLLEMA, B.E. Perineal hernia repair in the dog by transposition of the internal obturator muscle - II Complications and results in 100 patients. The Veterinary Quarterly, v. 11, n. 1, p. 18-23, 1989 b. 
VIII - APÊNDICES 


\section{APÊNDICE A}

\begin{tabular}{|c|l|l|c|c|l|}
\hline No. & MORADIA & RAÇA & $\begin{array}{c}\text { IDADE } \\
\text { (anos) }\end{array}$ & $\begin{array}{c}\text { PESO } \\
\text { CORPORAL } \\
(\mathrm{Kg})\end{array}$ & $\begin{array}{c}\text { DIAGNÓSTICO } \\
\text { EFETUADO POR: }\end{array}$ \\
\hline 1 & Apartamento & Poodle & 11,5 & 5 & Médico veterinário \\
\hline 2 & Casa & Lhasa Apso & 9 & 7,4 & HOVET/FMVZ/USP \\
\hline 3 & Apartamento & Poodle & 10 & 6,2 & Médico veterinário \\
\hline 4 & Apartamento & Pinscher & 16 & 3,4 & Médico veterinário \\
\hline 5 & Casa & Poodle & 9 & 10,2 & HOVET/FMVZ/USP \\
\hline 6 & Apartamento & Yorkshire & 8 & 7,1 & HOVET/FMVZ/USP \\
\hline 7 & Casa & SRD & 6 & 10,2 & Médico veterinário \\
\hline 8 & Apartamento & SRD & 12 & 19 & HOVET/FMVZ/USP \\
\hline 9 & Casa & Fox paulistinha & 14 & 8,4 & HOVET/FMVZ/USP \\
\hline 10 & Casa & $\begin{array}{l}\text { SRD } \\
\text { (mestiço poodle) }\end{array}$ & 8 & 6,8 & Médico veterinário \\
\hline
\end{tabular}

Quadro 1 - Informações alusivas ao tipo de moradia, raça, idade, peso e diagnóstico original dos animais da espécie canina, machos portadores de hérnia perineal submetidos a tratamento cirúrgico por elevação do músculo obturador interno com ou sem retalho de pericárdio de eqüino conservado em glicerina a $98 \%$ 


\section{APÊNDICE B}

\begin{tabular}{|c|c|c|c|c|}
\hline No. & EVOLUÇÃO & $\begin{array}{c}\text { SINTOMAS } \\
\text { OBSERVADOS }\end{array}$ & $\begin{array}{c}\text { ASPECTO } \\
\text { DAS FEZES }\end{array}$ & $\begin{array}{c}\text { ESCORE } \\
\text { EVACUAÇÃO }\end{array}$ \\
\hline 1 & 1 mês & $\begin{array}{l}\text { Disquesia } 30 \text { dias } \\
\text { Tenesmo } 15 \text { dias }\end{array}$ & $\begin{array}{c}\text { Fita pastoso } \\
\text { Pedaços duros }\end{array}$ & 3 \\
\hline 2 & 1 mês & $\begin{array}{l}\text { Disquesia } 60 \text { dias } \\
\text { Emese esporádica }\end{array}$ & Pedaços duros & 2 \\
\hline 3 & 5 meses & Nega & Pedaços duros & 0 \\
\hline 4 & 12 meses & Disquesia 2 anos & Pedaços duros & 2 \\
\hline 5 & 5 meses & $\begin{array}{l}\text { Hiporexia } 5 \text { dias } \\
\text { Disquesia } 5 \text { dias } \\
\text { Tenesmo } 5 \text { dias }\end{array}$ & $\begin{array}{c}\text { Fita pastoso } \\
\text { Estrias de } \\
\text { sangue }\end{array}$ & 1 \\
\hline 6 & 3 dias & $\begin{array}{l}\text { Disquesia } 21 \text { dias } \\
\text { Prurido anal } 60 \text { dias } \\
\text { Incontinência urinária }\end{array}$ & Fita pastoso & 2 \\
\hline 7 & 3 meses & $\begin{array}{l}\text { Disquesia } 5 \text { meses } \\
\text { Tenesmo } 3 \text { meses }\end{array}$ & Fita pastoso & 2 \\
\hline 8 & 2 meses & $\begin{array}{l}\text { Disquesia } 15 \text { dias } \\
\text { Emese esporádica }\end{array}$ & $\begin{array}{l}\text { Fita pastoso } \\
\text { Estrias de } \\
\text { sangue }\end{array}$ & 3 \\
\hline 9 & 12 meses & $\begin{array}{l}\text { Hiporexia } 7 \text { dias } \\
\text { Disquesia } 12 \text { meses } \\
\text { Tenesmo } 7 \text { dias }\end{array}$ & $\begin{array}{l}\text { Fita pastoso } \\
\text { Estrias de } \\
\text { sangue }\end{array}$ & 3 \\
\hline 10 & 2 meses & $\begin{array}{l}\text { Hiporexia } 2 \text { meses } \\
\text { Emese esporádica } \\
\text { Disquesia } 3 \text { meses }\end{array}$ & Fita pastoso & 2 \\
\hline
\end{tabular}

Quadro 2 - Dados referentes à evolução, sintomas observados, aspecto das fezes e escore de evacuação pertinentes aos animais portadores de hérnia perineal submetidos a tratamento cirúrgico por elevação do músculo obturador interno com ou sem retalho de pericárdio de eqüino conservado em glicerina a $98 \%$ 
APÊNDICE C

\begin{tabular}{|c|c|c|c|c|c|}
\hline No. & CONSISTÊNCIA & PALPAÇÃO & $\begin{array}{l}\text { ULTRA - } \\
\text { SOM }\end{array}$ & RAIO - X & $\begin{array}{c}\text { TRANS - } \\
\text { OPERATÓRIO }\end{array}$ \\
\hline 1 & Mista & $\begin{array}{l}\text { Próstata } \\
\text { Impactação } \\
\text { fecal (pouco) }\end{array}$ & $\begin{array}{l}\text { Próstata } \\
\text { Alças } \\
\text { intestinais } \\
\text { Líquido livre }\end{array}$ & $\begin{array}{l}\text { Uretra } \\
\text { prostática }\end{array}$ & $\begin{array}{l}\text { Gordura } \\
\text { Próstata }\end{array}$ \\
\hline 2 & Mista & $\begin{array}{l}\text { Próstata } \\
\text { Bexiga } \\
\text { Impactação } \\
\text { fecal (pouco) }\end{array}$ & $\begin{array}{l}\text { Alças } \\
\text { intestinais } \\
\text { Líquido livre }\end{array}$ & $\begin{array}{l}\text { Uretra } \\
\text { prostática }\end{array}$ & $\begin{array}{l}\text { Gordura } \\
\text { Aderências }\end{array}$ \\
\hline 3 & Macio & $\begin{array}{l}\text { Impactação } \\
\text { fecal } \\
\text { Alças } \\
\text { intestinais }\end{array}$ & $\begin{array}{l}\text { Bexiga } \\
\text { Próstata } \\
\text { Líquido livre }\end{array}$ & $\begin{array}{l}\text { Uretra } \\
\text { prostática } \\
\text { em canal } \\
\text { pélvico }\end{array}$ & $\begin{array}{l}\text { Bexiga } \\
\text { Epíplon }\end{array}$ \\
\hline 4 & Mista & $\begin{array}{l}\text { Próstata } \\
\text { Impactação } \\
\text { fecal (pouco) }\end{array}$ & $\begin{array}{l}\text { Próstata } \\
\text { Alça intestinal } \\
\text { (reto) }\end{array}$ & $\begin{array}{l}\text { Não } \\
\text { realizado }\end{array}$ & $\begin{array}{l}\text { Próstata } \\
\text { Gordura }\end{array}$ \\
\hline 5 & Macio & Próstata & $\begin{array}{l}\text { Próstata } \\
\text { Bexiga }\end{array}$ & $\begin{array}{l}\text { Próstata } \\
\text { Bexiga } \\
\text { retrofletida }\end{array}$ & $\begin{array}{l}\text { Gordura } \\
\text { Bexiga } \\
\text { Próstata }\end{array}$ \\
\hline 6 & Mista & $\begin{array}{l}\text { Próstata } \\
\text { Impactação } \\
\text { fecal (pouco) }\end{array}$ & $\begin{array}{l}\text { Próstata } \\
\text { Alça com } \\
\text { fezes }\end{array}$ & $\begin{array}{l}\text { Uretra } \\
\text { prostática }\end{array}$ & $\begin{array}{l}\text { Gordura } \\
\text { Próstata }\end{array}$ \\
\hline 7 & Firme & $\begin{array}{l}\text { Próstata } \\
\text { Impactação } \\
\text { fecal }\end{array}$ & $\begin{array}{lr}\text { Parte } & \text { da } \\
\text { bexiga } & \\
\text { Próstata } & \\
\text { Alças } & \text { com } \\
\text { fezes } & \\
\end{array}$ & $\begin{array}{l}\text { Uretra } \\
\text { prostática } \\
\text { dilatada }\end{array}$ & Epíplon \\
\hline 8 & Firme & $\begin{array}{l}\text { Impactação } \\
\text { fecal (pouco) }\end{array}$ & $\begin{array}{l}\text { Alça com } \\
\text { fezes e gases }\end{array}$ & $\begin{array}{l}\text { Sem } \\
\text { alterações } \\
\text { dignas de } \\
\text { nota }\end{array}$ & Gordura \\
\hline 9 & Macio & Próstata & $\begin{array}{l}\text { Próstata } \\
\text { Bexiga } \\
\text { Alça }\end{array}$ & $\begin{array}{l}\text { Bexiga } \\
\text { retrofletida } \\
\text { Uretra } \\
\text { prostática } \\
\text { Alças } \\
\text { intestinais }\end{array}$ & $\begin{array}{l}\text { Gordura } \\
\text { Bexiga } \\
\text { Próstata } \\
\text { Epíplon }\end{array}$ \\
\hline 10 & Firme & $\begin{array}{l}\text { Impactação } \\
\text { fecal } \\
\text { (fecaloma) }\end{array}$ & $\begin{array}{l}\text { Alça } \quad \text { com } \\
\text { fezes }\end{array}$ & $\begin{array}{l}\text { Alças com } \\
\text { conteúdo } \\
\text { fecal }\end{array}$ & $\begin{array}{l}\text { Gordura } \\
\text { Epíplon } \\
\text { Lume retal } \\
\text { aumentado }\end{array}$ \\
\hline
\end{tabular}

Quadro 3 - Aspectos relacionados à consistência da região perineal, órgãos palpáveis e observados ao ultra-som, exame radiográfico e durante o transoperatório nos animais submetidos a tratamento cirúrgico por elevação do músculo obturador interno com ou sem retalho de pericárdio de eqüino conservado em glicerina a $98 \%$ 


\section{APÊNDICE D}

\begin{tabular}{|c|c|c|c|c|c|c|}
\hline No. & EVOLUÇÃO & LADO & COCCÍGEO & $\begin{array}{l}\text { ELEVADOR } \\
\text { ÂNUS }\end{array}$ & $\begin{array}{l}\text { ESFÍNCTER } \\
\text { ANAL }\end{array}$ & OBTURADOR \\
\hline & & & ATROFIA & ATROFIA & ATROFIA & ATROFIA \\
\hline 1 & 1 mês & $\mathrm{D}$ & Discreta & Severa & Severa & Moderada \\
\hline 2 & 1 mês & $\mathrm{E}$ & Discreta & Severa & Discreta & Discreta \\
\hline 3 & 5 meses & $\mathrm{D}$ & Moderada & Severa & Discreta & Ausente \\
\hline 4 & 12 meses & $\mathrm{E}$ & Moderada & Moderada & Ausente & Discreta \\
\hline 5 & 5 meses & $\mathrm{D}$ & Moderada & Severa & Ausente & Ausente \\
\hline 6 & 3 dias & $\mathrm{D}$ & Discreta & Moderada & Discreta & Ausente \\
\hline 7 & 3 meses & $\mathrm{D}$ & Ausente & Discreta & Ausente & Ausente \\
\hline 8 & 2 meses & $\mathrm{E}$ & Discreta & Moderada & Moderada & Ausente \\
\hline 9 & 12 meses & $\mathrm{D}$ & Ausente & Severa & Moderada & Ausente \\
\hline 10 & 2 meses & $\mathrm{E}$ & Discreta & Moderada & Discreta & Ausente \\
\hline
\end{tabular}

Quadro 4 - Tempo de evolução, lado acometido e condição da musculatura durante o período transoperatório nos pacientes submetidos a herniorrafia por elevação do músculo obturador interno com ou sem reforço de retalho de pericárdio de eqüino

\begin{tabular}{|c|c|c|c|c|}
\hline No. & LADO & CONTEÚDO & PO IMEDIATO & PO TARDIO \\
\hline 1 & $\mathrm{D}$ & $\begin{array}{l}\text { Gordura } \\
\text { Próstata }\end{array}$ & $\begin{array}{l}\text { Tenesmo } \\
\text { RECIDIVA } \\
\text { Incontinência fecal } \\
\text { Infecção } \\
\text { Evisceração } \\
2^{\mathrm{a}} \text { intervenção cirúrgica }\end{array}$ & $\begin{array}{l}\text { Fragilidade do diafragma } \\
\text { contralateral } \\
\text { Bexiga deslocada para canal } \\
\text { pélvico }\end{array}$ \\
\hline 2 & $\mathrm{E}$ & $\begin{array}{l}\text { Gordura } \\
\text { Aderências }\end{array}$ & $\begin{array}{l}\text { Edema firme discreto } \\
\text { eritema }\end{array}$ & $\begin{array}{l}\text { Bexiga deslocada para canal } \\
\text { pélvico }\end{array}$ \\
\hline 3 & $\mathrm{D}$ & $\begin{array}{l}\text { Bexiga } \\
\text { Epíplon }\end{array}$ & $\begin{array}{l}\text { Hiporexia } \\
\text { Aquesia } \\
\text { Edema firme discreto }\end{array}$ & $\begin{array}{l}\text { RECIDIVA (60 dias) } \\
\text { Bexiga deslocada para canal } \\
\text { pélvico }\end{array}$ \\
\hline 4 & $\mathrm{E}$ & $\begin{array}{l}\text { Gordura } \\
\text { Próstata }\end{array}$ & $\begin{array}{l}\text { Disquesia } \\
\text { Edema firme discreto } \\
\text { Seroma }\end{array}$ & $\begin{array}{l}\text { Diafragma pélvico íntegro } \\
\text { Bexiga em posição anatômica }\end{array}$ \\
\hline 5 & $\mathrm{D}$ & $\begin{array}{l}\text { Gordura } \\
\text { Bexiga } \\
\text { Próstata }\end{array}$ & $\begin{array}{l}\text { Aquesia } \\
\text { Eritema } \\
\text { Seroma }\end{array}$ & $\begin{array}{l}\text { Fragilidade do diafragma } \\
\text { contra-lateral } \\
\text { Bexiga em posição anatômica }\end{array}$ \\
\hline
\end{tabular}

Quadro 5 - Lado acometido, conteúdo transoperatório e complicações pós-operatórias (PO) imediatas e tardias, nos animais submetidos a herniorrafia por elevação do músculo obturador interno sem reforço de retalho de pericárdio eqüino 


\section{APÊNDICE E}

\begin{tabular}{|c|c|c|c|c|}
\hline No. & LADO & CONTEÚDO & PO IMEDIATO & PO TARDIO \\
\hline 6 & $\mathrm{D}$ & $\begin{array}{l}\text { Gordura } \\
\text { Próstata }\end{array}$ & $\begin{array}{l}\text { Incontinência fecal } \\
\text { Eritema } \\
\text { Edema firme local } \\
\text { Seroma } \\
\text { Incontinência fecal }\end{array}$ & $\begin{array}{l}\text { Incontinência urinária noturna } \\
\text { Diafragma pélvico íntegro } \\
\text { Bexiga em posição anatômica }\end{array}$ \\
\hline 7 & $\mathrm{D}$ & Epíplon & Edema firme discreto & $\begin{array}{l}\text { Diafragma pélvico íntegro } \\
\text { Bexiga deslocada para canal } \\
\text { pélvico }\end{array}$ \\
\hline 8 & $\mathrm{E}$ & Gordura & Edema firme & $\begin{array}{l}\text { Integridade do diafragma } \\
\text { pélvico } \\
\text { Bexiga em posição anatômica }\end{array}$ \\
\hline 9 & $\mathrm{D}$ & $\begin{array}{l}\text { Gordura } \\
\text { Bexiga } \\
\text { Próstata } \\
\text { Epíplon }\end{array}$ & $\begin{array}{l}\text { Disquesia } \\
\text { Incontinência urinária } \\
\text { Seroma } \\
\text { Edema firme }\end{array}$ & Óbito \\
\hline 10 & $\mathrm{E}$ & $\begin{array}{l}\text { Lume retal } \\
\text { aumentado } \\
\text { Gordura } \\
\text { Epíplon }\end{array}$ & Edema firme & $\begin{array}{l}\text { Integridade do diafragma } \\
\text { pélvico } \\
\text { Bexiga em posição anatõmica }\end{array}$ \\
\hline
\end{tabular}

Quadro 6 - Lado acometido, conteúdo transoperatório e complicações pós-operatórias (PO) imediatas e tardias, nos animais submetidos a herniorrafia por elevação do músculo obturador interno com reforço de retalho de pericárdio eqüino. 


\section{APÊNDICE F}

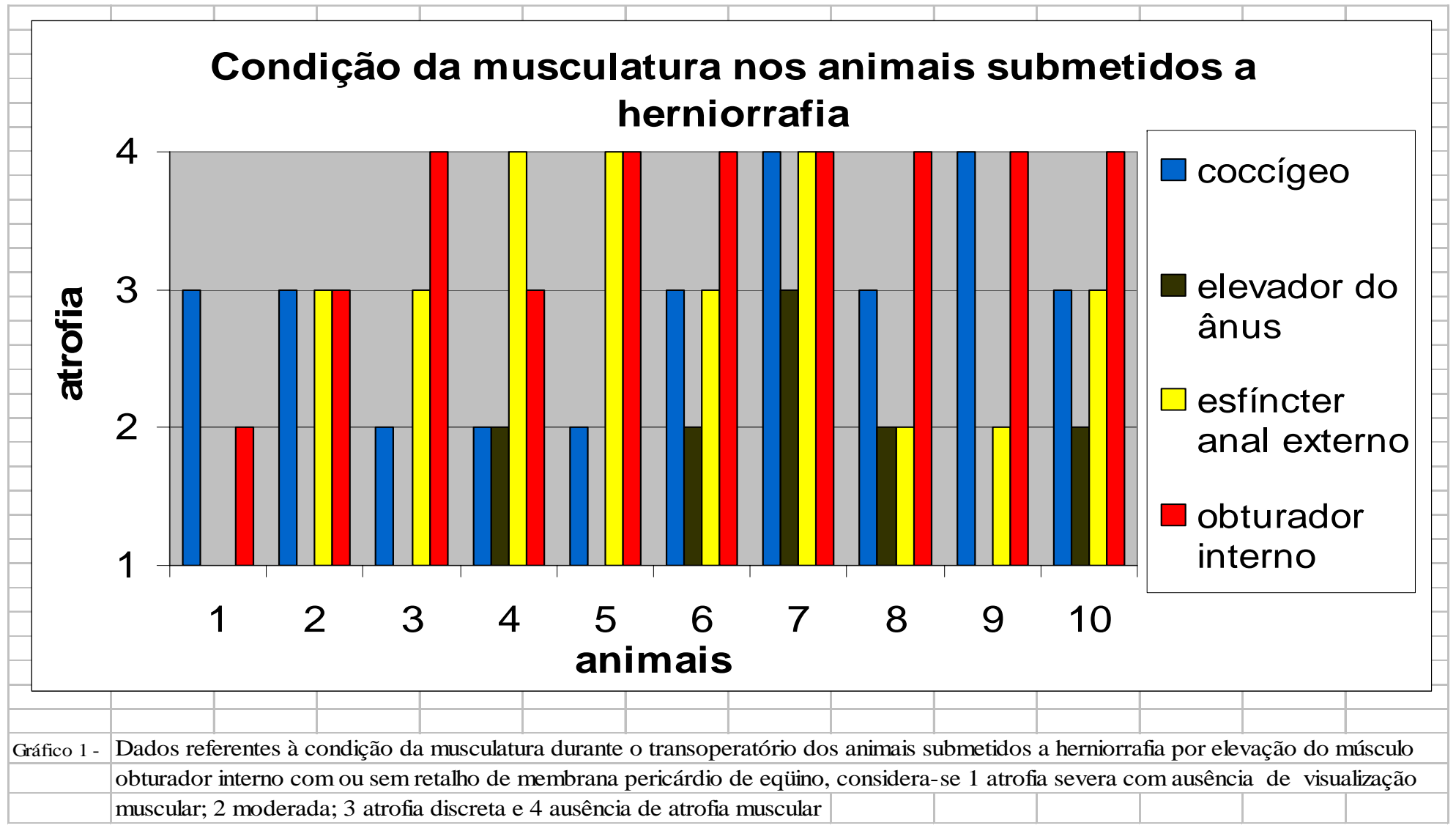


APÊNDICE G - Herniorrafia por elevação do músculo obturador interno associado a colocação de membrana pericárdio de eqüino preservado em glicerina a 98\%. Intervenção cirúrgica animal n. 7

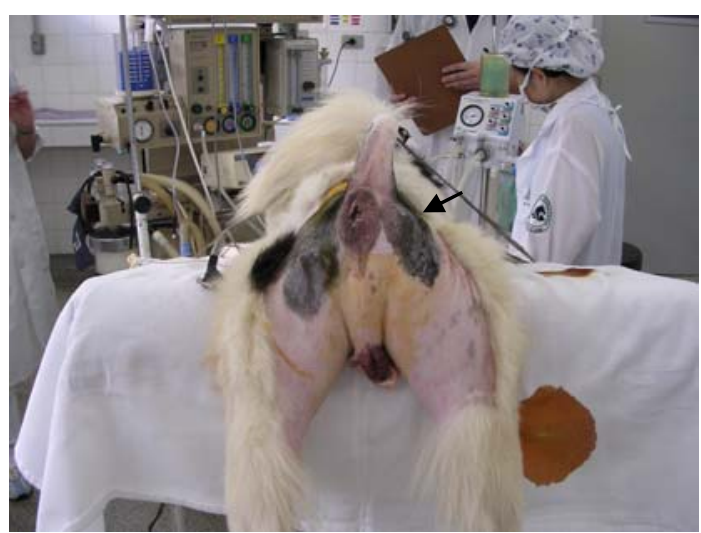

Figura 1 - Observa-se o posicionamento do animal. Notar aumento de volume em região perineal direita, deslocando o ânus para a esquerda .

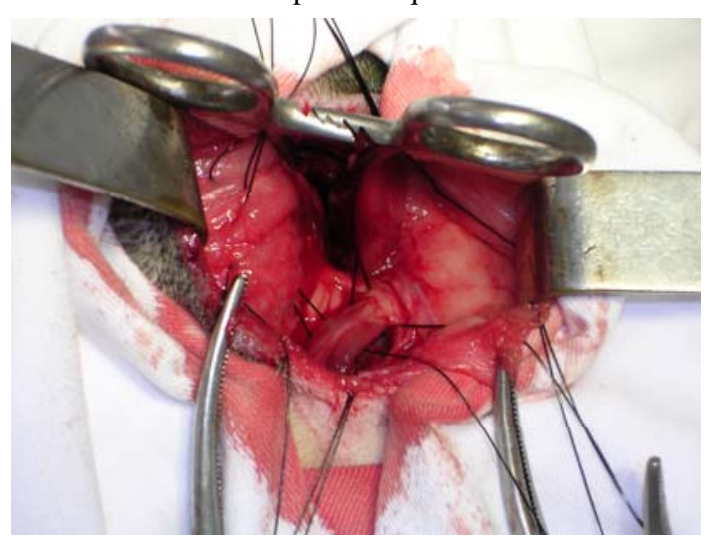

Figura 4 - Observar suturas aplicadas e visualização do músculo obturador interno com a sutura.

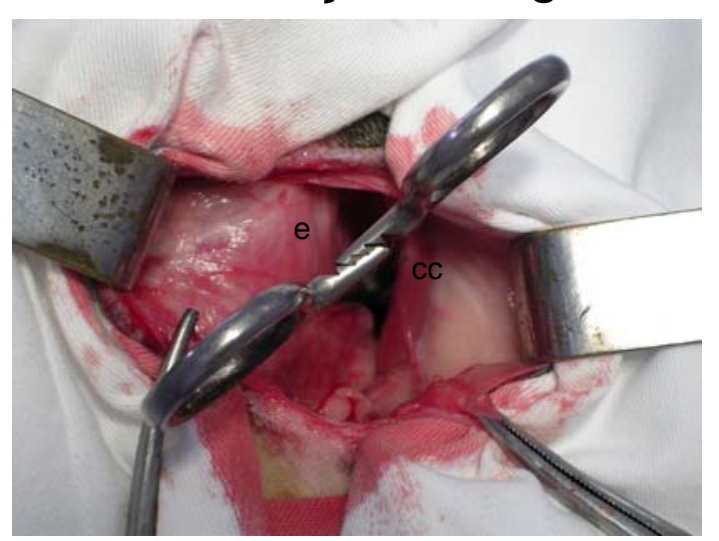

Figura 2 - Redução do conteúdo herniário para a cavidade abdominal e identificação dos músculos coccígeo (cc) e esfíncter externo do ânus (e).

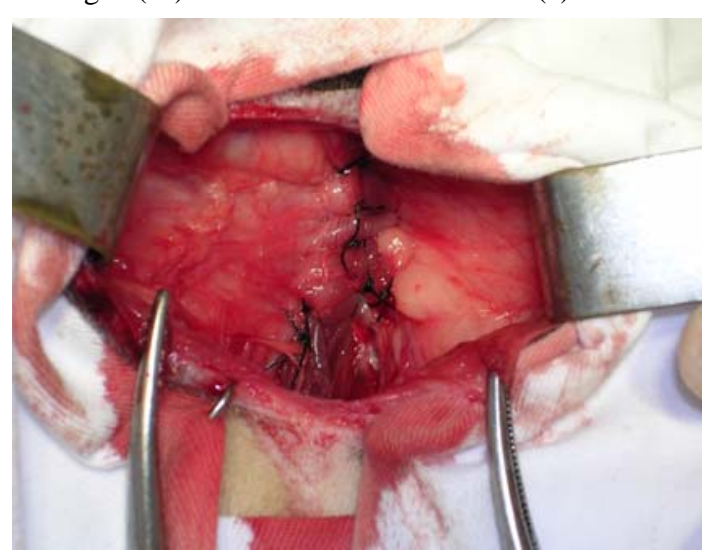

Figura 5 - Observar aspecto da herniorrafia por elevação do músculo obturador interno já concluída.

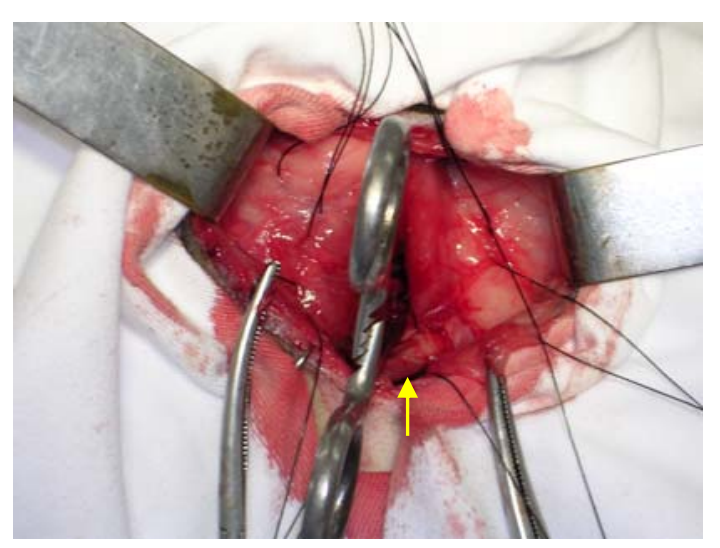

Figura 3 - Observar a aplicação de suturas para fechamento do defeito perineal. Nota o músculo obturador já elevado, em região ventral (seta).

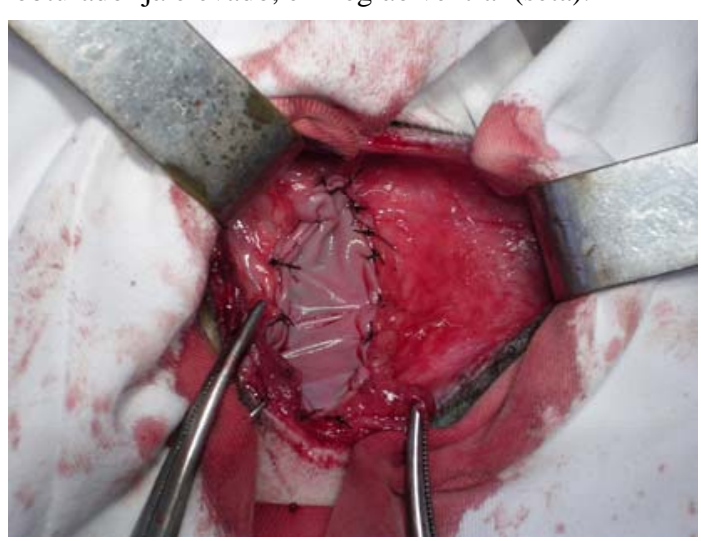

Figura 6 - Observar aplicação da membrana pericárdio de eqüino preservado em glicerina a $98 \%$. 
APÊNDICE H - Pós operatório de herniorrafia por elevação do músculo obturador interno associado a colocação de membrana pericárdio de eqüino preservado em glicerina a $98 \%$. Animal n. 7

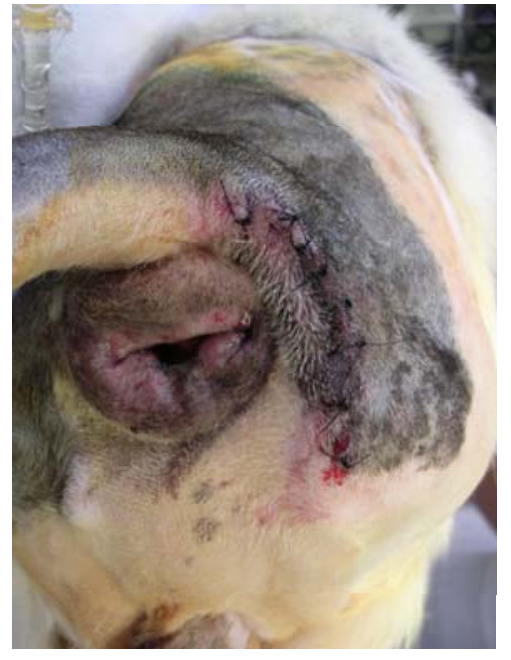

Figura 7 - Aspecto PO ao término da intervenção cirúrgica. Notar relaxamento e edemaciamento do ânus.

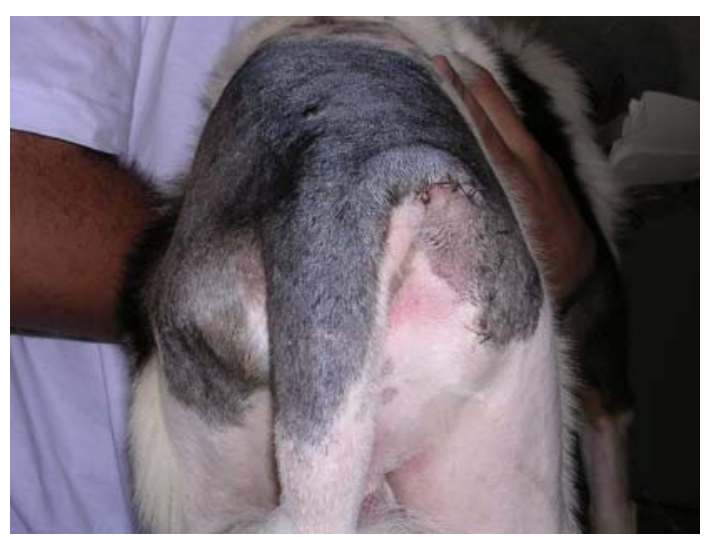

Figura 10 - Aspecto lateral no 7o dia PO. Notar persistência do edema firme e eritema na ferida cirúrgica.
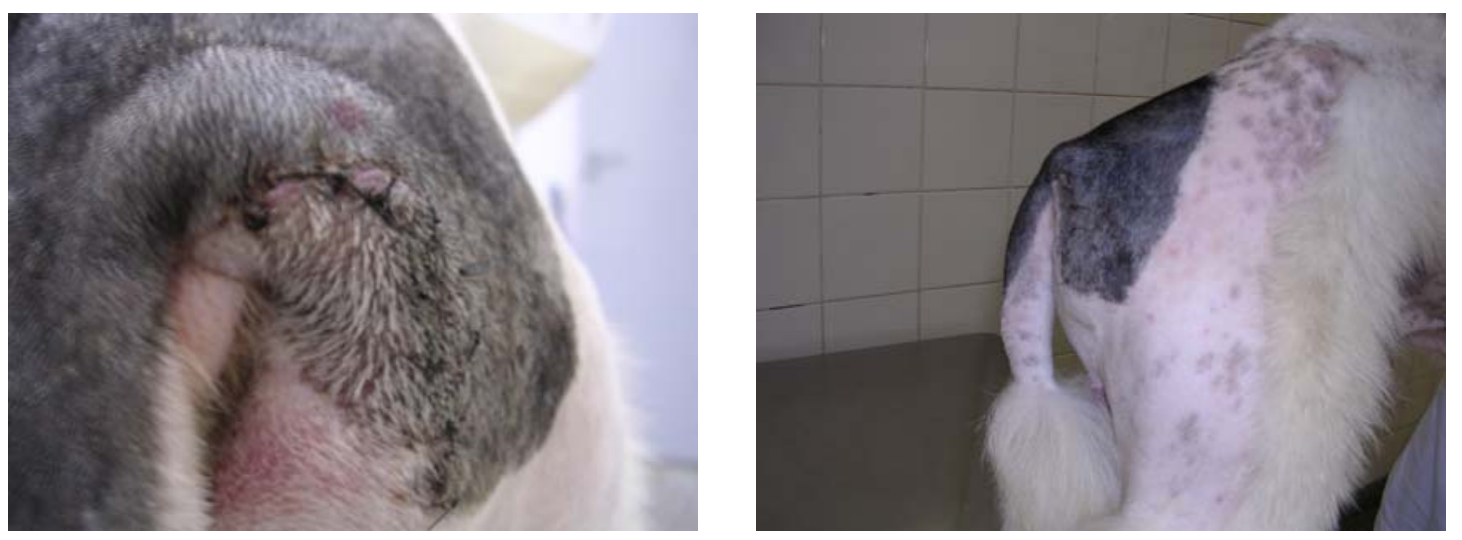

Figura 8 - Aspecto caudal no 3o dia PO. Notar edema firme e eritema na ferida cirúrgica.

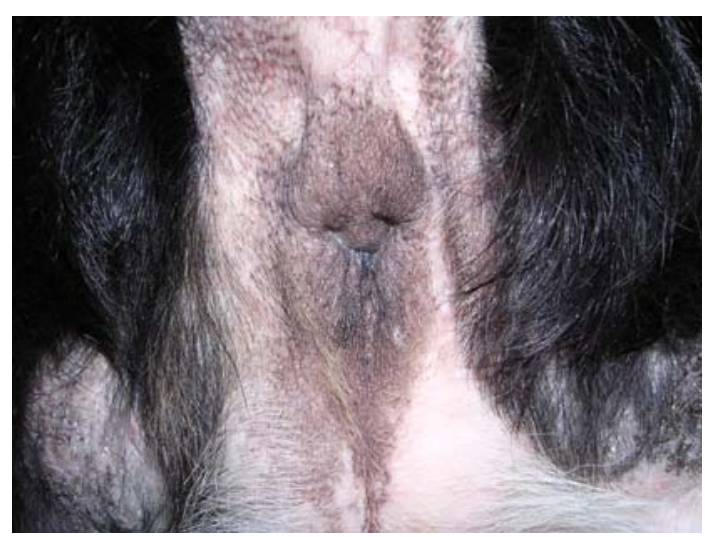

Figura 11 - Aspecto caudal da região perineal aos 90 dias de PO.
Figura 9 - Aspecto lateral no 7o dia PO. Notar edema firme e eritema na ferida cirúrgica.

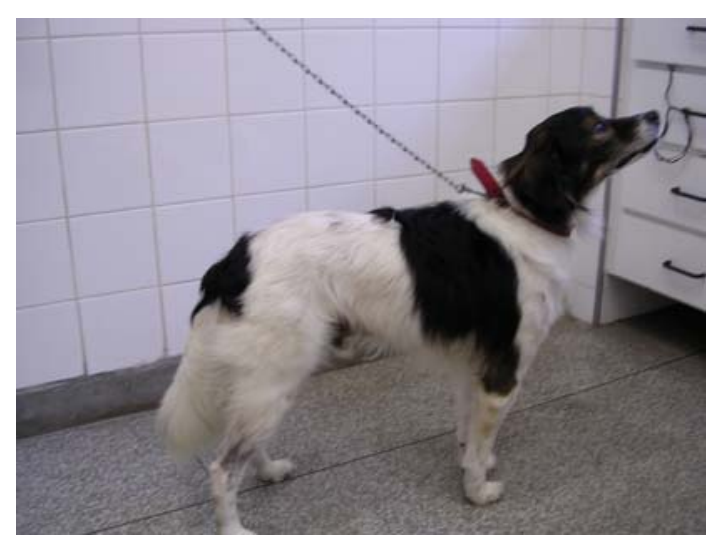

Figura 12 - Aspecto lateral da região perineal aos 90 dias de $\mathrm{PO}$ 
APÊNDICE I - Preparo do paciente para herniorrafia por elevação do músculo obturador interno associado a colocação de membrana de pericárdio de eqüino preservado em glicerina a 98\%. Intervenção cirúrgica animal n. 9

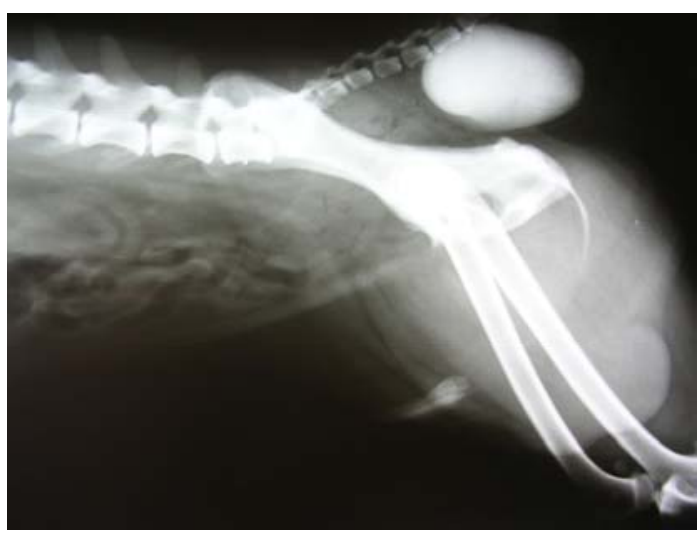

Figura 13 - Uretrocistografia excretora. Projeção látero - lateral, evidenciando vesícula urinária retrofletida para o interior do saco herniário

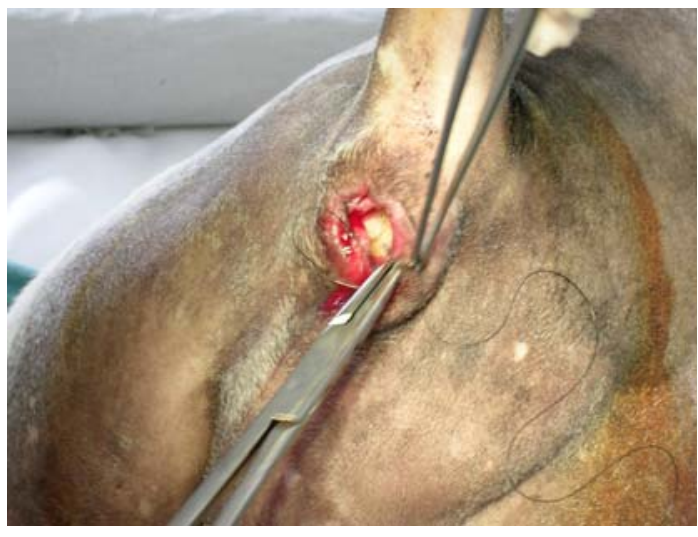

Figura 16 - Aplicação da sutura em bolsa de fumo na região anal.

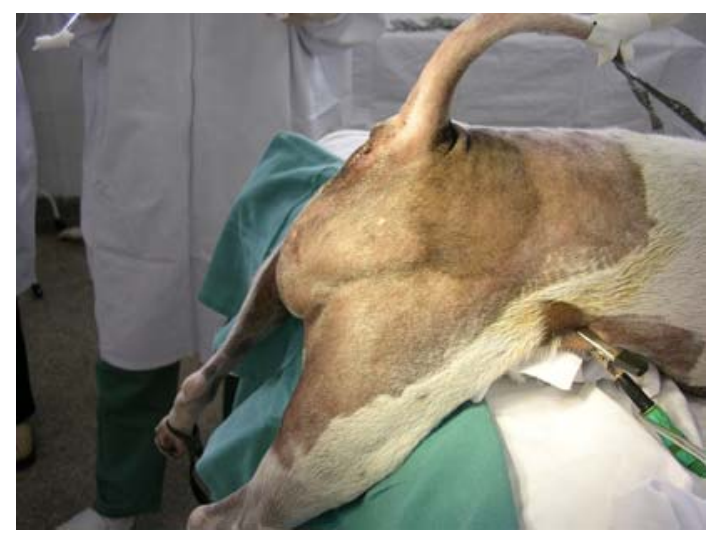

Figura 14 - Posicionamento em decúbito esternal com acolchoamento na região inguinal (Trendelenburger)

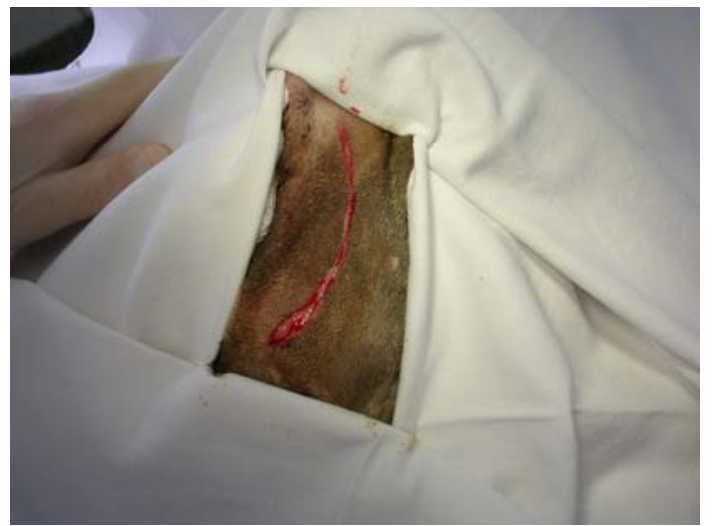

Figura 17 - Colocação dos panos de campo cirúrgico. Demonstração da incisão semicircular na pele em região perineal.

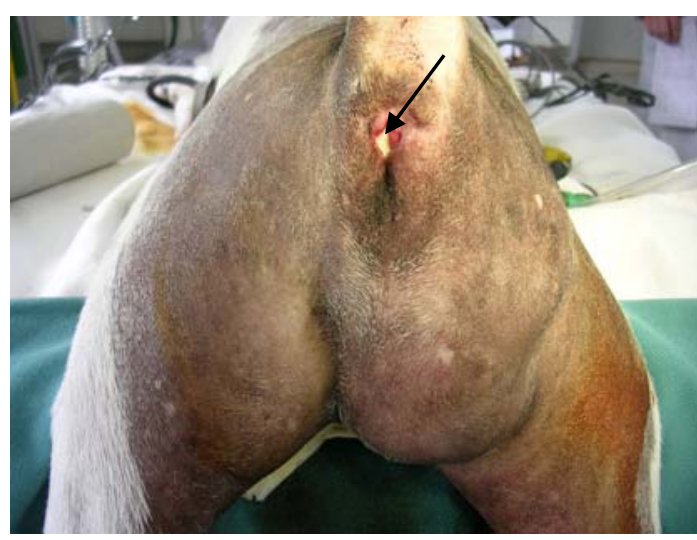

Figura 15 -Notar a presença de gaze introduzida no lúmen do reto para evitar o extravasamento de fezes (seta).

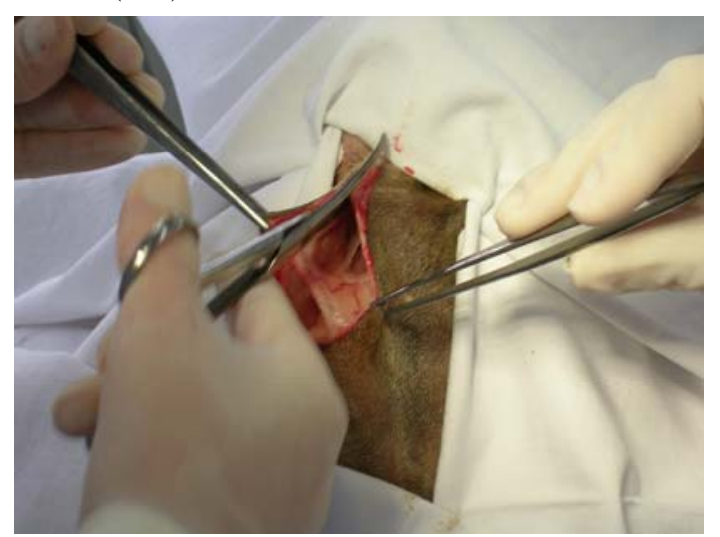

Figura 18 - Incisão do tecido subcutâneo adjacente e rompimento do saco herniário. 
APÊNDICE J - Herniorrafia por elevação do músculo obturador interno associado a colocação de membrana de pericárdio de eqüino preservado em glicerina a 98\%. Intervenção cirúrgica animal n. 9

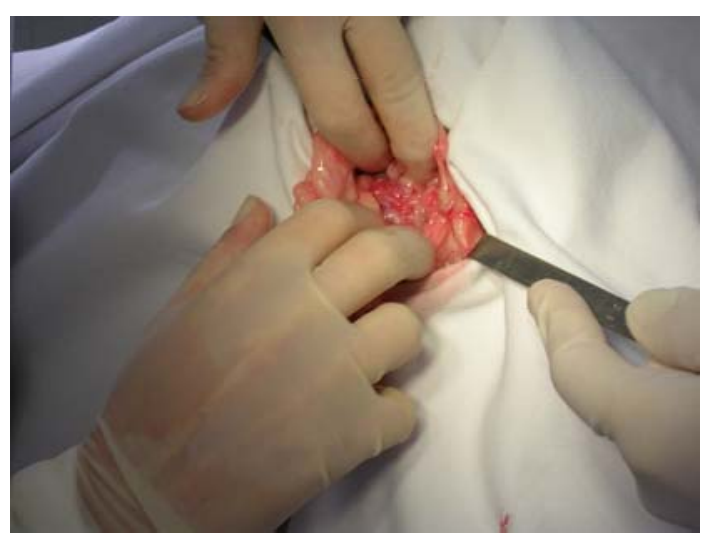

Figura 19 - Rompimento do "saco" herniário seguido de divulsão romba delicada para individualização do conteúdo herniado.

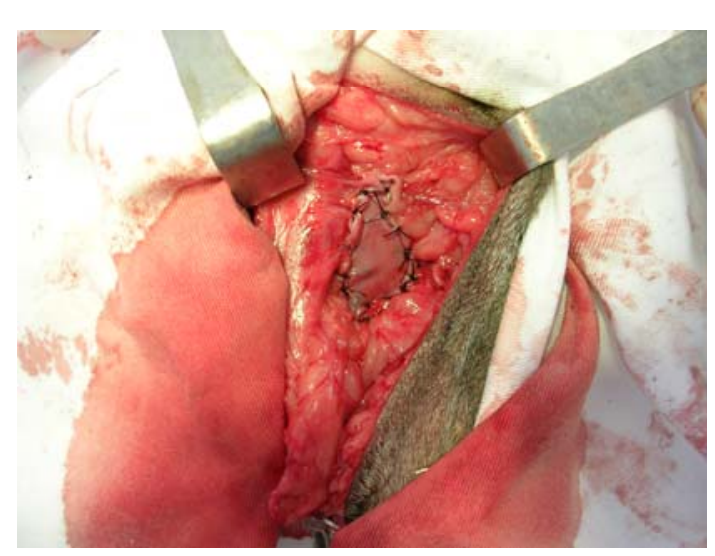

Figura 21 - Colocação da membrana pericárdio de eqüino preservado em glicerina a $98 \%$ sobre a herniorrafia.

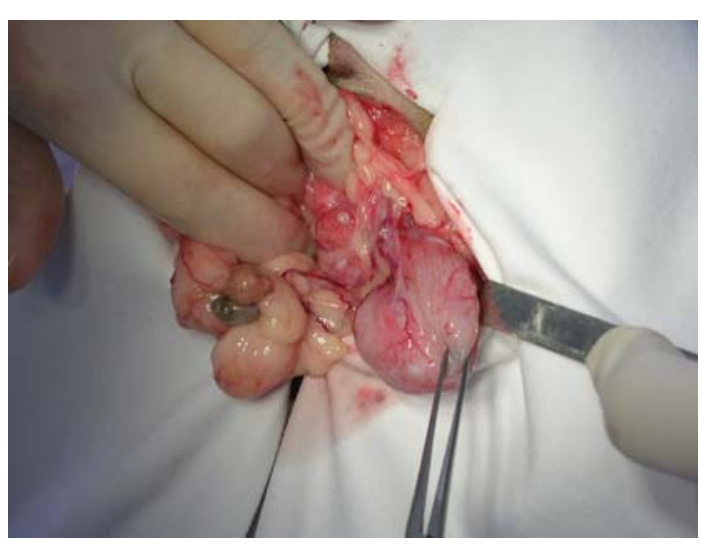

Figura 20 - Visualização das estruturas presentes no saco herniário. Notar a vesícula urinária como parte do conteúdo, identificada pela pinça anatômica.

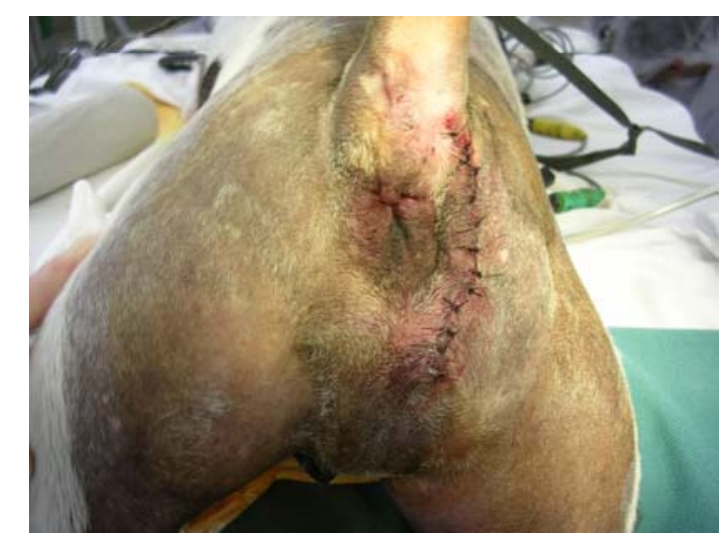

Figura 22 - Aspecto final da intervenção cirúrgica proposta. Notar sutura em bolsa de fumo ainda presente no ânus e ausência de extravasamento de 
APÊNDICE K - Pós operatório de herniorrafia por elevação do músculo obturador interno associado a colocação de membrana de pericárdio de eqüino preservado em glicerina a 98\%. Animal n. 9

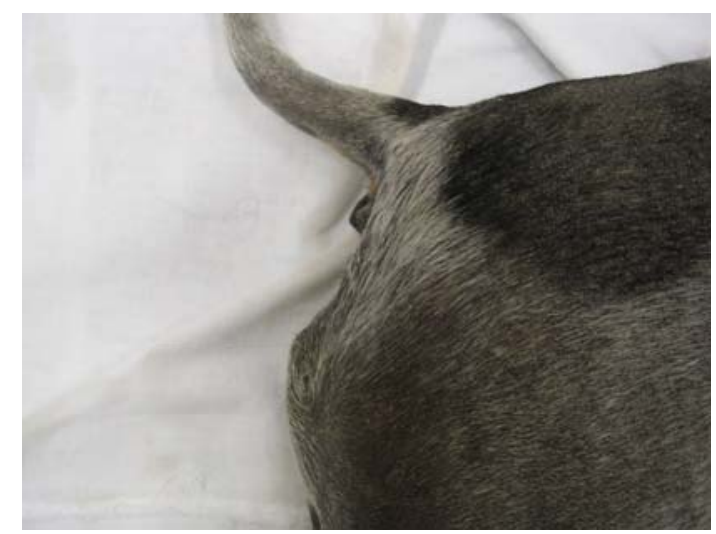

Figura 23 - Aspecto lateral da região perineal após aproximadamente 30 dias de PO.

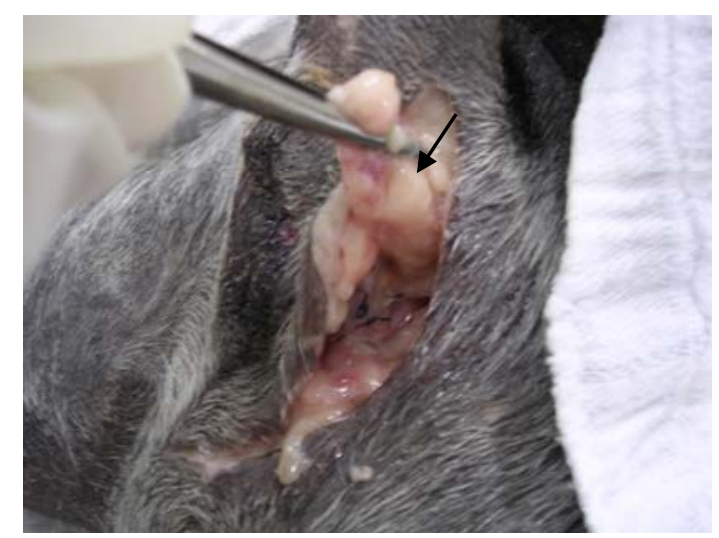

Figura 26 - Tecido gorduroso e reação de fibrose junto à musculatura. Notar pontos da herniorrafia realizada.

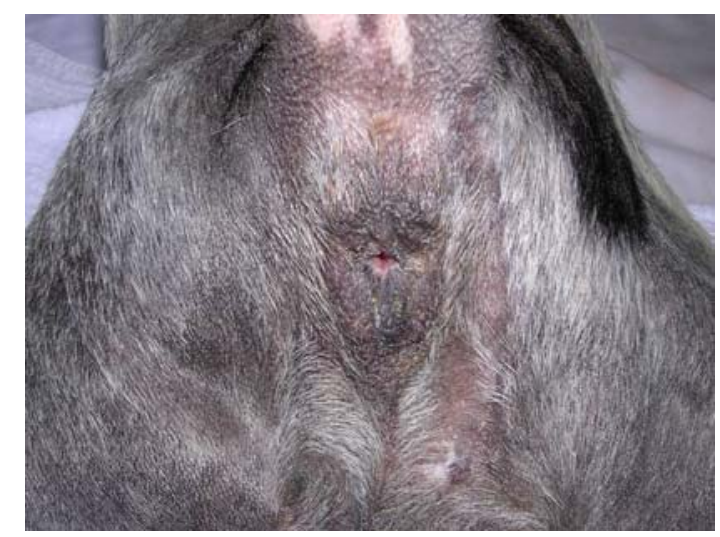

Figura 24 - Aspecto caudal da região perineal após aproximadamente 30 dias de PO.

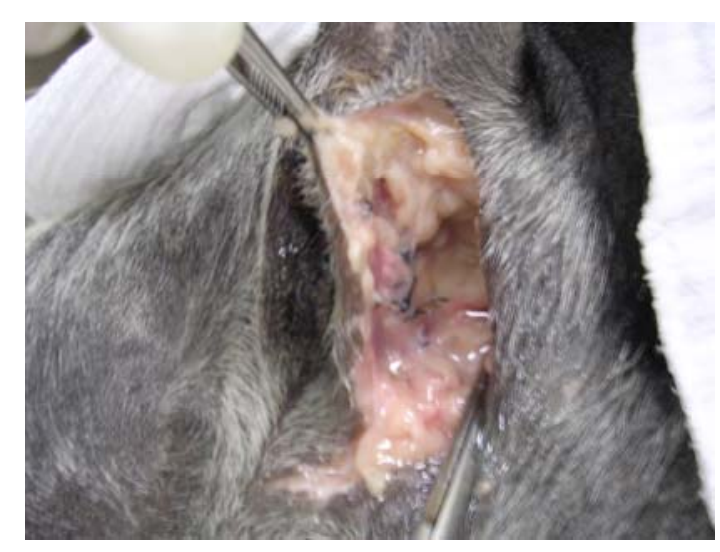

Figura 27 - Membrana bem adaptada ao tecido muscular conferindo resistência à região.

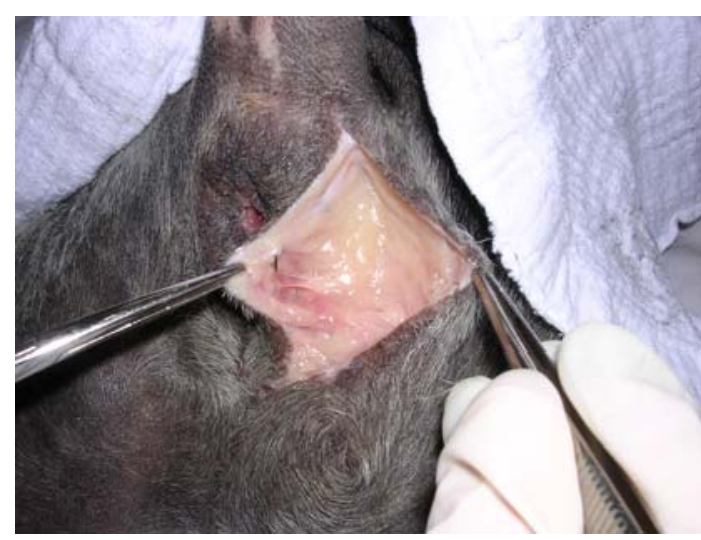

Figura 25 - Acesso ao local submetido à intervenção cirúrgica, no animal em necróspia após aproximadamente 30 dias de PO.

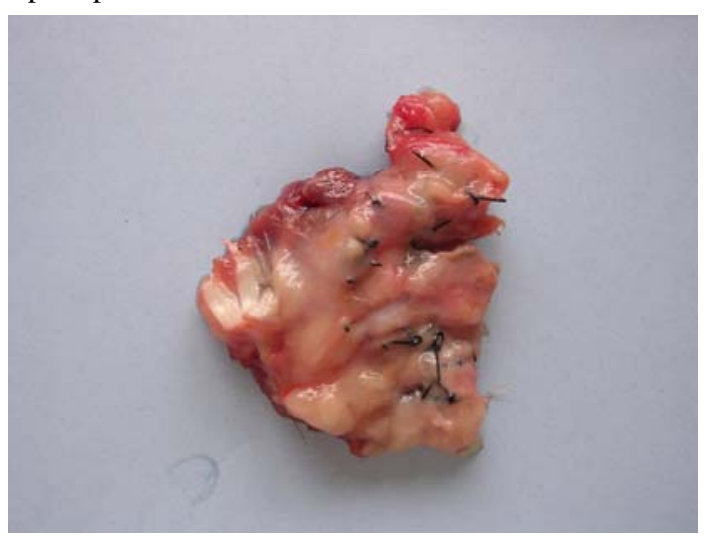

Figura 28 - Retirada do conjunto de músculos utilizados para a herniorrafia, evidenciando que a membrana foi incorporada à região. 


\section{APÊNDICE L - Preparo da membrana pericárdio de eqüino preservado em glicerina a $98 \%$ e aplicação sobre a herniorrafia por elevação do músculo obturador interno}

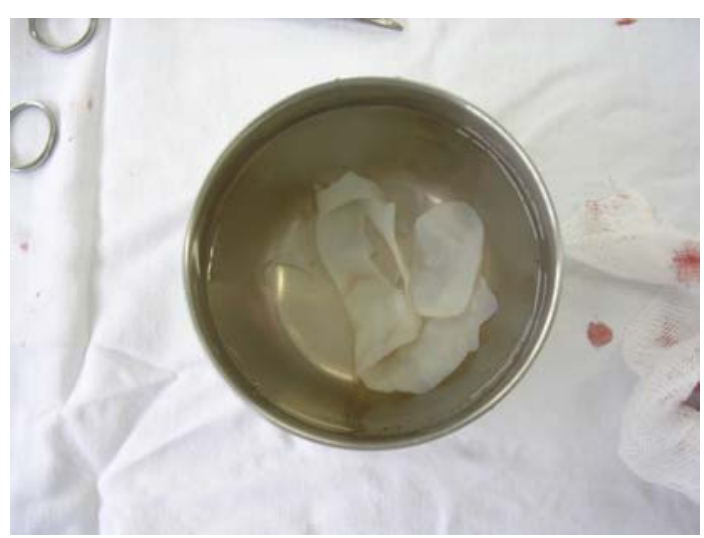

Figura 29 - Rehidratação em solução fisiológica (SF) do retalho de pericárdio de eqüino preservado em glicerina a $98 \%$ após submetido à lavagem com SF de $\mathrm{NaCl}$ a $0,9 \%$

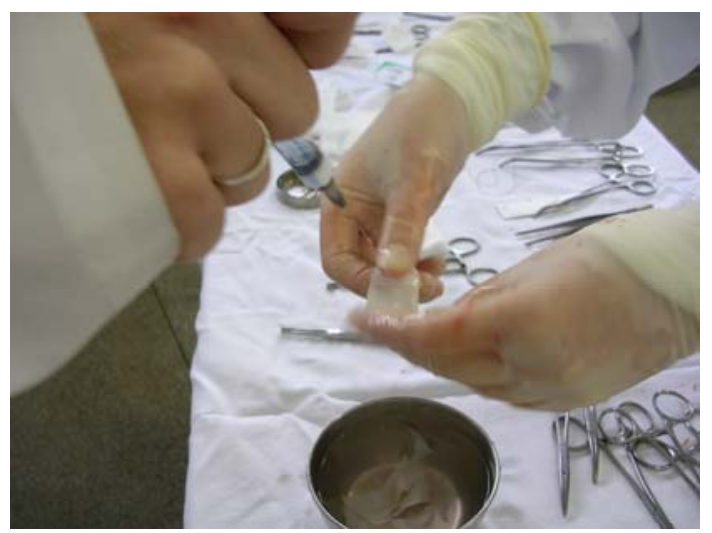

Figura 30 - Embebecimento do retalho com solução de antibiótico ampicilina na concentração de $100 \mathrm{mg} / \mathrm{ml}$ antes da aplicação no sítio cirúrgico.

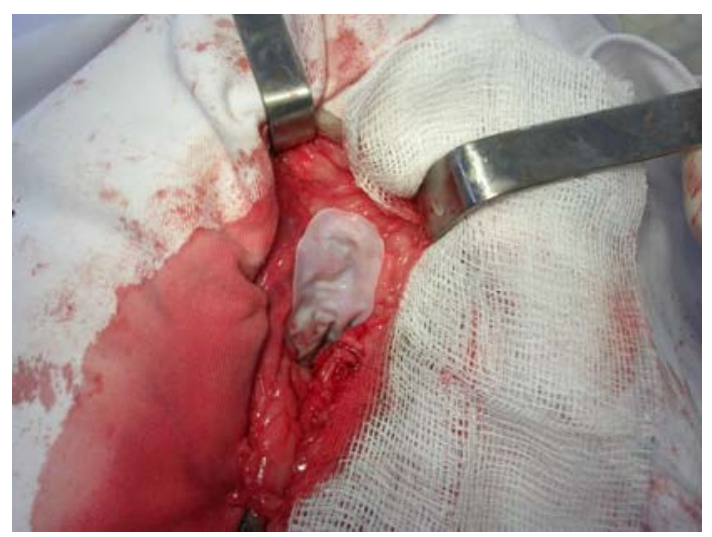

Figura 31 - Aplicação do retalho de tamanho suficiente para cobrir a região do diafragma pélvico, anteriormente reconstruído.

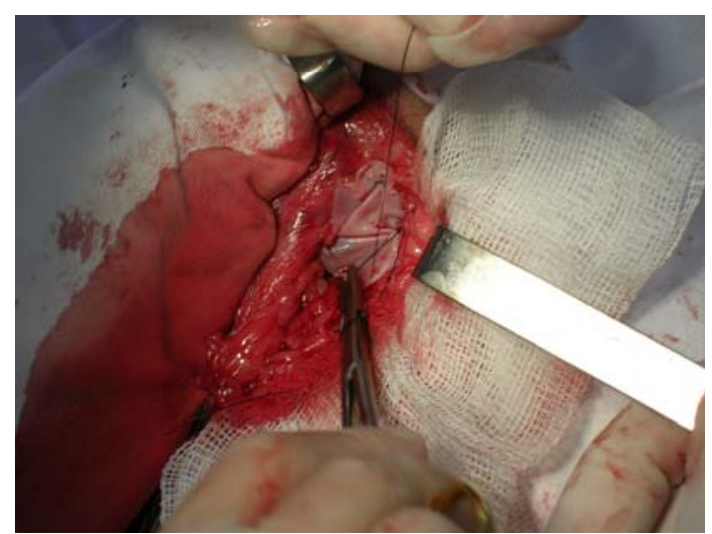

Figura 32 - Realização dos primeiros 4 pontos de apoio para sutura da membrana junto à musculatura.

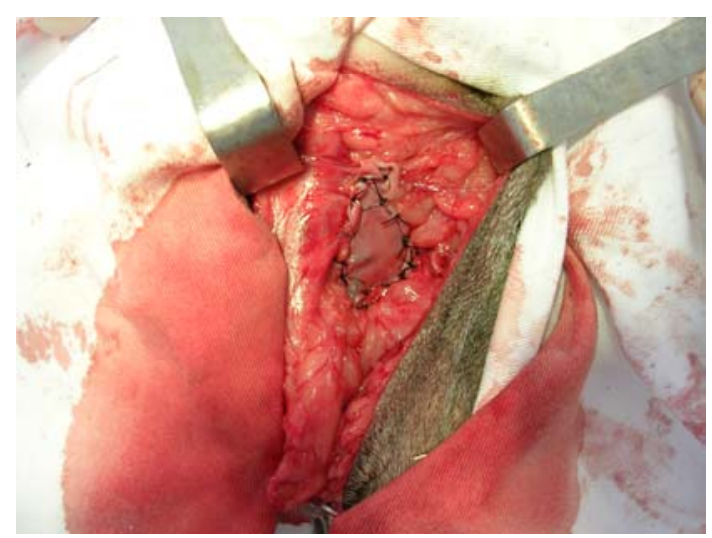

Figura 33 - Finalização dos pontos necessários para manter o pericárdio de eqüino justaposto à musculatura . 